\title{
A TRAJETÓRIA DE ABILON DE SOUZA NAVES NO PTB PARANAENSE (1945-1959)
}

\author{
Abilon de Souza Naves' path at the PTB Party at \\ Paraná (1945-1959)
}

\author{
Alessandro Batistella*
}

\begin{abstract}
RESUMO
À frente do Partido Trabalhista Brasileiro paranaense por mais de dez anos, Abilon de Souza Naves conseguiu reestruturar e fortalecer o partido, consolidando-se como a principal liderança trabalhista no Paraná, inclusive elegendo-se senador em 1958. Considerado o virtual governador eleito em 1960, Souza Naves faleceu repentinamente em dezembro de 1959, vitimado por um ataque cardíaco fulminante. Portanto, o presente artigo pretende analisar a trajetória de Abilon de Souza Naves no PTB do Paraná, focando especialmente a sua ascensão dentro do partido, as disputas políticas e a sua consolidação como principal liderança petebista no Paraná.
\end{abstract}

Palavras chave: Souza Naves; PTB; Paraná.

\begin{abstract}
Ahead of the Brazilian Labor Party at the state of Paraná for more than ten years Abilon de Souza Naves managed to restructure and strengthen the partv . consolidating himself as the leading Labor leadership in Paraná, even if elected senator in 1958. Considered the virtual governor elected in 1960 . Souza Naves died suddenlv in December 1959 . victim of a massive heart attack. Therefore. this article analvzes the traiectorv of Abilon de Souza Naves in the Paraná PTB , especially focusing his rise within the party, political disputes and its consolidation as main PTB leadership in Paraná.
\end{abstract}

Key words: Souza Naves; PTB Party; Paraná.

* Doutor em História pela Universidade Federal do Rio Grande do Sul (UFRGS). Professor do curso de História da Universidade de Passo Fundo/RS (UPF). 


\section{Introdução}

Abilon de Souza Naves nasceu em 1905, em Uberaba (MG) e chegou ao Paraná em meados da década de 1940. Contador de formação, atuou como delegado regional do Instituto de Aposentadoria e Pensões dos Comerciários (IAPC) e trabalhou na área comercial do jornal Gazeta do Povo (NEVES, 2002, p. 138).

Em 1946, Souza Naves, que possuía vínculos de amizade com Moysés Lupion, passou a gerenciar o jornal Diário Popular (órgão trabalhista financiado por Lupion) e ascendeu à Comissão Executiva Estadual do PTB do Paraná como vice-presidente. Em 1948, após a morte de Maximino Zanon, Souza Naves passou a presidir provisoriamente o partido, até ser eleito presidente efetivo da Executiva Estadual em outubro de 1949.

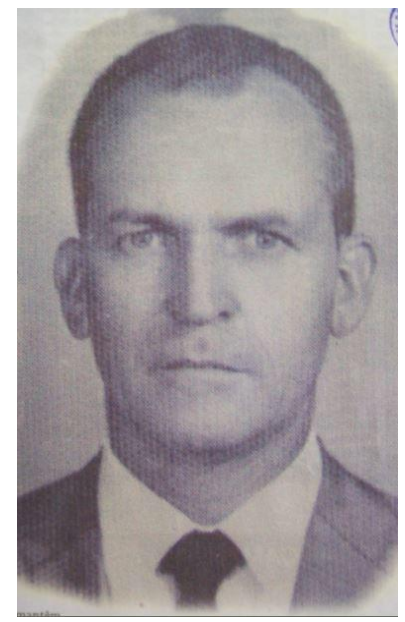

Imagem 1 Abilon de Souza Naves. Fonte: Gazeta do Povo, 12 dez. 1999. Biblioteca Pública do Paraná, Divisão de Documentação Paranaense. Pasta Biografias.

Após algumas disputas internas dentro do partido, Souza Naves foi gradativamente consolidando-se como a principal liderança trabalhista do Paraná e integrou a Executiva Nacional do partido, 
onde era um fiel aliado de Getúlio Vargas e João Goulart. Permanecendo no comando do PTB paranaense por mais de dez anos, Souza Naves conseguiu reestruturar e fortalecer o partido, que se consolidaria como uma das principais forças políticas do Paraná ao longo da década de 1950. Nas eleições de 1958, Souza Naves elegeuse senador e era considerado como o virtual governador eleito nas eleições de 1960. Porém, faleceu em dezembro de 1959, vitimado por um ataque cardíaco fulminante.

Portanto, o presente artigo pretende analisar a trajetória de Abilon de Souza Naves no PTB do Paraná, focando especialmente a sua ascensão dentro do partido, as disputas políticas e a sua consolidação como principal liderança petebista no Paraná.

\section{A gênese e os anos iniciais do PTB no Paraná}

Embora o governo Vargas contasse com o apoio de uma expressiva parcela da população brasileira, sobretudo os trabalhadores urbanos, no início de 1945 o fim do Estado Novo e a volta do país ao regime democrático mostravam-se inevitáveis. Sofrendo pressões internas $^{1}$ e externas ${ }^{2}$, o governo Vargas buscou planejar e conduzir o processo de transição pelo alto, visando a garantir a manutenção do seu poder na nova ordem institucional (DELGADO, 2003, p. 133134).

Durante esse processo de transição pelo alto, o governo adotou uma série de medidas estratégicas. Primeiramente, a 28 de fevereiro de 1945, decretou o Ato Adicional $\mathrm{n}^{\circ}$ 9, estabelecendo eleições diretas para a presidência da República e proporcionais para

1 A partir de 1943, as vozes que clamavam pelo retorno do país ao regime democrático passaram a ecoar cada vez mais alto, pois diversos setores da sociedade - estudantes, intelectuais, empresários, comunistas, liberais, militares e até mesmo integrantes do governo - passaram a pressionar cada vez mais Getúlio Vargas pelo fim da ditadura estadonovista.

2 A pressão externa pela redemocratização do Brasil aumentava com a derrocada dos países do Eixo e a iminente vitória dos países aliados, comprometidos com os valores da democracia liberal. 
o Congresso Nacional. Em seguida, no dia 18 de abril, decretou anistia geral a seus adversários políticos, beneficiando inclusive os comunistas. Posteriormente, a 28 de maio de 1945, o governo decretou a chamada Lei Agamenon (em referência a Agamenon Magalhães, ministro da Justiça da época), no qual marcou as eleições para o dia 2 de dezembro e regulamentou o novo código eleitoral e os requisitos para a formação dos partidos políticos. A grande inovação da referida lei era a obrigatoriedade, pela primeira vez na história republicana, da formação de partidos de caráter nacional ${ }^{3}$.

Contudo, alguns partidos já estavam se articulando antes mesmo da promulgação da Lei Agamenon, dentre estes a União Democrática Nacional (UDN), o Partido Social Democrático (PSD) e o Partido Trabalhista Brasileiro (PTB), que são considerados "criaturas de Vargas", uma vez que gravitavam - de maneiras distintas - em torno da figura do ditador estadonovista.

A União Democrática Nacional, oficialmente fundada em 7 de abril de 1945, surgiu como uma grande frente liberal-democrática de oposição ao Estado Novo e a Getúlio Vargas. Inicialmente, a UDN aglutinava grupos políticos bastante heterogêneos - quando não antagônicos - unidos em torno da reconquista das liberdades democráticas e do combate a um inimigo comum - o ditador estadonovista. Além da oposição sistemática a Vargas, esse heterogêneo ${ }^{4}$ grupo apoiava a candidatura do Brigadeiro Eduardo Gomes na sucessão presidencial.

3 Aqui não podemos deixar de mencionar uma exceção: o Partido Comunista Brasileiro (PCB), único partido político de caráter nacional existente no país antes de 1945. Fundado em 1922 e com um programa partidário-ideológico bem definido, o partido, apesar da sua situação de clandestinidade, "conseguir manter, mesmo durante a ditadura do Estado Novo, uma estrutura organizacional nacional ancorada nas capitais e principais cidades do país" (SOARES, 1981, p. 7).

4 No entanto, como era esperado, não tardou para que houvesse as primeiras cisões no seio dessa grande coalizão oposicionista. Um dos primeiros grupos a romper com a UDN foi a Esquerda Democrática, em agosto de 1945. Formada por políticos e intelectuais socialistas e antigetulistas, a Esquerda Democrática daria origem ao Partido Socialista Brasileiro (PSB), no início de 1946 (BODEA, 1992). Ainda durante o ano de 1945, a UDN conviveu com novas dissidências, o que levou a formação de outros partidos, como o Partido Libertador (PL), o Partido Republicano (PR) e o Partido Republicano Progressista - todos partidos de menor representatividade em nível nacional e mais ou menos fortes em determinados estados da federação. Em particular, o Partido Republicano Progressista, registrado em novembro de 1945, foi formado pelo ex-interventor de São Paulo Adhemar de Barros, em fusão com o grupo de João Café Filho, do Rio Grande do Norte. Em junho de 1946, o Partido Republicano Progressista fundiu-se com outros dois pequenos partidos de 
No Paraná, em fevereiro de 1945 os grupos opositores a Getúlio Vargas no estado começaram a articular a Frente Única do Paraná, que reunia, entre outros nomes, o major Plínio Tourinho, Joaquim Pereira de Macedo, Laerte Munhoz, Arthur Ferreira dos Santos, Erasto Gaertner, Francisco de Paula Soares Neto, Otávio da Silveira, Bento Munhoz da Rocha Neto (filho de Caetano Munhoz da Rocha ${ }^{5}$ ), o jornalista Caio Machado, o intelectual David Carneiro e o engenheiro Othon Mader.

No início de março de 1945, a Frente Única do Paraná é lançada oficialmente por meio de um manifesto (Cf. Gazeta do Povo, 10 mar. 1945, p. 3), no qual dava início a uma campanha sistemática à candidatura do Brigadeiro Eduardo Gomes e à volta do Território do Iguaçu ${ }^{6}$ à jurisdição do Estado do Paraná. No final de maio, a Frente Única ingressou na União Democrática Nacional (UDN) (Gazeta do Povo, 31 maio 1945, p. 5). Portanto, a Frente Única foi o germe da UDN no Paraná.

Por sua vez, do lado das forças getulistas de continuísmo ocorreu um processo de formação de duas correntes distintas: o Partido Social Democrático (PSD) e o Partido Trabalhista Brasileiro (PTB), "que trariam em suas estruturas e bases organizativas resquícios do Estado Novo" (DELGADO, 1989, p. 27-28). Como dois irmãos siameses, o PSD e o PTB surgiram como partidos getulistas naquela conjuntura de redemocratização pelo alto: "[...] Se ao PSD caberia atuar para garantir uma transição conservadora e capaz de manter antigos poderes e privilégios, ao PTB seria destinada a função de legitimar, frente aos trabalhadores, os termos de uma mudança que não seria mais do que uma "transição permitida"' (DELGADO, 1989, p. 31).

origem paulista (o Partido Popular Sindicalista e o Partido Agrário Nacional), dando origem ao Partido Social Progressista (PSP) (SAMPAIO, 1981, p. 176).

5 Durante a República Velha, Caetano Munhoz da Rocha presidiu o Paraná durante dois mandatos consecutivos: 1920-1924 e 1924-1928.

$6 \mathrm{O}$ Território Federal do Iguaçu submetia-se diretamente ao governo federal. Foi criado pelo Decreto Lei ${ }^{\circ} 5.812$, de 13 de setembro de 1943, e abrangia a região dos municípios paranaenses de Foz do Iguaçu, Iguaçu e Clevelândia, além da região oeste de Santa Catarina. Abrangendo regiões de fronteiras internacionais, o Território do Iguaçu foi criado sob a justificativa de envolver problemas de integridade e segurança nacional e de buscar-se a sua integração ao território nacional. 
O PSD procurou aglutinar as forças políticas tradicionais, reunindo em seus quadros integrantes da máquina administrativa do governo, os interventores estadonovistas, representantes das oligarquias estaduais e alguns segmentos da classe média urbana e da burguesia nacional. Dessa forma, o PSD nasceu com uma sólida infra-estrutura administrativa e clientelista nos diversos estados da federação (DELGADO, 2003, p. 138-139), o que permitiu ao partido lograr êxitos eleitorais.

No Paraná, o PSD foi articulado pelo interventor Manoel Ribas e por integrantes dos altos escalões da máquina administrativa estadual, como o Major Fernando Flores, Roberto Glaser, Angelo Lopes, João Teófilo Gomy Júnior, Lauro Sodré Lopes, e os irmãos Flávio Guimarães, Alô Guimarães e Acyr Guimarães (jornalista e proprietário do jornal Gazeta do Povo), entre outros.

A definição do formato do PSD praticamente estabeleceu os contornos do outro partido "situacionista": ele deveria reunir as lideranças sindicais que também vinham resistindo ao projeto de uma só organização partidária. Em outras palavras, o PTB nasceu simultaneamente ao PSD, já que ambos resultaram da frustração do projeto de partido único de massas que vinha sendo acalentado pelo Estado Novo (GOMES, 2005, p. 281-282).

Inspirado no modelo do Partido Trabalhista Inglês, o PTB ancorou suas bases a partir da estrutura do Ministério do Trabalho, utilizando-se das lideranças sindicais e dos organismos previdenciários (GOMES, 2005, p. 283). Desta forma, o PTB, de acordo com Angela de Castro Gomes (2007, p. 57-58), não foi uma "invenção de última hora"; pelo contrário, ele surgiu como a coroação organizacional de um longo e cuidadoso esforço de construção de uma ideologia trabalhista no Brasil, que mobilizou muitos recursos humanos, técnicos e financeiros, particularmente no próprio Ministério do Trabalho.

Elegendo os sindicatos como o seu principal local de atuação, o objetivo do PTB era atrair e mobilizar as camadas populares, principalmente nos grandes centros urbanos, para a órbita do partido, apresentando-se como a agremiação partidária que levaria os trabalhadores a alcançar os seus direitos. No entanto, o PTB não foi criado para ser um "partido dos trabalhadores, mas um "partido para os trabalhadores", pois também objetivava ser um anteparo ao Partido 
Comunista Brasileiro (PCB), que, legalizado, disputaria a simpatia (e os votos) dos assalariados urbanos.

A formação de uma Comissão Executiva Nacional para organizar o partido data de 15 de maio de 1945, porém a data oficial da criação do PTB, segundo os registros legais existentes, é 26 de março de 1945 (D’ARAÚJO, 1996, p. 24).

No Paraná, o PTB teve sua origem diretamente relacionada ao sindicalismo oficial, pois o partido surgiu da União dos Trabalhadores do Paraná (UTP), que era uma espécie de intersindical que aglutinava diversas federações e sindicatos de todo o estado. A UTP foi arquitetada pelo interventor Manoel Ribas e por políticos ligados à interventoria do estado, como o Major Fernando Flores e o advogado trabalhista Milton Viana, que articularam com os líderes sindicais estadonovistas a criação da entidade, cujo objetivo era canalizar o sindicalismo ligado ao Estado Novo em uma frente de defesa do legado trabalhista de Getúlio Vargas. Entre os principais líderes da UTP estavam os sindicalistas Lúcio de Freitas, Maximino Zanon, João Tavares Santana, Alfredo Santana Ribeiro e Bernardino Fialho Sobrinho.

Contando com o apoio decisivo da máquina administrativa estadual, durante o primeiro semestre de 1945 os dirigentes sindicais da UTP visitaram inúmeras cidades do interior do estado com o intuito de angariar adesões e fundar filiais da entidade nestas localidades. No entanto, o objetivo era mais amplo: criar condições mínimas de estruturação do PTB no estado por meio do sindicalismo estadonovista. Ademais, outro objetivo dos dirigentes da UTP era defender a candidatura do gen. Eurico Dutra (PSD) para a presidência da República (Diário da Tarde, 7 jul. 1945, p. 1). Portanto, a UTP não esteve ligada ao movimento queremista ${ }^{7}$.

O PTB no Paraná foi oficialmente fundado no domingo do dia 8 de julho de 1945, no qual a UTP - que se transformaria no PTB - preparou uma grande Convenção Estadual, realizada na Sociedade

$7 \mathrm{O}$ movimento queremista iniciou como um movimento popular que era favorável ao continuísmo de Vargas e que era discretamente apoiado pelo Ministério do Trabalho, pelo DIP e por empresários. Ancorados no lema era "Queremos Getúlio", a partir do final de julho e início de agosto o movimento ganhou grande projeção nacional, com manifestações e comícios em todo o país, no qual defendiam a candidatura de Getúlio Vargas nas eleições de dezembro. 
Duque de Caxias, em Curitiba, que contou com a presença do sindicalista Luís Augusto França (então presidente nacional do partido) do interventor Manoel Ribas, de políticos que pertenciam à máquina política estadual e ao PSD e diversos líderes sindicais de todo o estado. Nessa oportunidade ficou definida a primeira Comissão Executiva do PTB no Paraná, presidida pelo líder sindical Maximino Zanon $^{8}$ e composta por Lúcio de Freitas (presidente de honra), Vitor Barbosa (secretário), José de Moura (tesoureiro), Bernardino Fialho Sobrinho, José Barbosa de Almeida e Astrogildo Souza (conselho fiscal) (Cf. O Dia, 10 jul. 1945, p. 3).

Os primeiros meses de existência do PTB paranaense foram marcados pela inauguração de alguns diretórios pelo interior do estado, aproveitando a estrutura deixada pelos núcleos da UTP nestas cidades, e pelo apoio à candidatura do General Eurico Gaspar Dutra, pelo PSD, à presidência da República 9 .

Entretanto, o PTB do Paraná, assim como em todo o país, nasceu como um partido estruturalmente fraco e sem disponibilizar de recursos financeiros, o que contribuiu para o seu fraco desempenho nas eleições de dezembro de $1945^{10}$.

8 Maximino Zanon, o primeiro presidente do PTB paranaense (e que permaneceria no cargo até a sua morte, em janeiro de 1948) foi alfaiate e jogou futebol no Britânia S.C. - time hexacampeão paranaense na década de 1920. Ainda na década de 1920, atuou em sociedades operárias beneficentes, sendo presidente da Sociedade Operária Beneficente da Água Verde. Na década de 1930, Zanon continuou atuando no movimento sindical, tendo sido um dos fundadores e o primeiro presidente da Federação das Sociedades Beneficentes Operárias do Paraná. Também atuou como árbitro de futebol e dirigente esportivo, tendo ocupando os cargos de presidente do Britânia S.C., presidente da Liga Curitibana de Esportes Atléticos, diretor da extinta Federação Paranaense de Desporto e diretor da Federação Paranaense de Futebol. Nos seus últimos anos de vida atuou como oficial do Cartório de Registro de Imóveis (Cf. Necrológios de Maximino Zanon. In: Gazeta do Povo, 23 jan. 1948, p. 3; Diário da Tarde, 22 jan. 1948, p. 6; O Dia, 23 jan. 1948, p. 5).

9 No entanto, com a derrota de Luís Augusto França e a vitória do grupo de Baeta Neves e Segadas Viana na I Convenção Nacional do PTB, realizada no final de agosto de 1945, consolidou-se a corrente antidutrista no partido. Assim, Maximino Zanon - agora integrante da Executiva Nacional, ocupando o posto de terceiro secretário - procurou imprimir ao PTB do Paraná partido às orientações do Diretório Nacional. A partir de então, a maior fração dos petebistas paranaenses adotaram uma posição dúbia em relação à sucessão presidencial: por um lado, não defendiam mais abertamente a candidatura do Gen. Dutra; por outro, continuavam a apoiá-lo de forma velada.

10 Nas eleições de 1945, o PTB do Paraná elegeu apenas um deputado federal: Getúlio Vargas. Neste sentido, convém lembrar que a Lei Agamenon permitia a candidatura múltipla, podendo o candidato concorrer simultaneamente para presidente, senador ou deputado federal num mesmo ou em mais estados. Getúlio Vargas, por exemplo, concorreu a deputado federal em sete 
Após as eleições de 1945 - cuja opção em lançar a candidatura de lideranças sindicais não logrou êxito - o PTB paranaense vivenciou um processo de "elitização" interna, com o ingresso de inúmeros políticos profissionais, empresários e profissionais liberais - sobretudo advogados e funcionários públicos , que gradativamente foram ocupando os principais postos de mando dentro do partido. Nesse sentido, convém ressaltar que a maioria desses novos integrantes do PTB eram pessoas que possuíam algum tipo de vínculo com o abastado empresário Moysés Lupion, o que contribuiu para o processo de "lupionização" do partido.

\section{A "lupionização" do PTB paranaense e a ascensão de Abilon de Souza Naves nas hostes petebistas}

Amigo de Manoel Ribas, Moysés Lupion passou a ser considerado, após a morte do ex-interventor (em janeiro de 1946) o seu herdeiro político. Proprietário de um verdadeiro império econômico, Lupion ambicionava chegar ao governo do Paraná nas eleições de 1947 e, para tais propósitos, utilizou-se de todo o seu poderio financeiro para promover a sua pré-candidatura, comprando jornais - como O Dia ${ }^{11}$, de Curitiba, e Correio do Paraná, de Londrina, além de $49 \%$ da Gazeta do Povo, de Curitiba - e emissoras de rádios, como a Rádio Sociedade Guairacá Ltda., em Curitiba que controlava seis outras emissoras no interior do Paraná (SALLES, 2004, p. 98).

estados e a senador em três, sendo eleito senador da República pelos estados do Rio Grande do Sul e São Paulo (sendo derrotado no Paraná) e eleito deputado federal por sete estados da federação: Bahia, Minas Gerais, Rio de Janeiro, Distrito Federal, São Paulo, Rio Grande do Sul e Paraná. Como Vargas optou em assumir a senatoria sul-rio-grandense, quem assumiu a legislatura petebista do Paraná foi o primeiro suplente Rubens de Mello Braga.

$11 \mathrm{O}$ jornal $O$ Dia foi arrendado junto ao governo paranaense por Lupion no início de 1946. Dirigido por Raul Vaz, amigo e homem de confiança de Lupion, esse jornal tornou-se o órgão oficial do lupionismo. Com grande circulação, propagandeou o nome de Lupion por todo o Paraná. 
Contudo, Lupion enfrentava dentro do PSD paranaense a concorrência de outro pré-candidato ao governo estadual: o interventor Brasil Pinheiro Machado ${ }^{12}$. As duas pré-candidaturas pessedistas (Pinheiro Machado e Moysés Lupion) à sucessão estadual de 1947 acabaram gerando uma crise política no Paraná e polarizando as posições não somente dentro do PSD, mas também no PTB paranaense, uma vez que havia dentro desses dois partidos uma pequena ala simpática ao interventor e outra forte corrente que defendia a candidatura de Lupion.

No PTB do Paraná, Lupion cooptou Maximino Zanon e o seu grupo, que passaram a defender incondicionalmente a sua candidatura ao governo estadual. Neste sentido, convém ressaltar que a candidatura do pessedista Moysés Lupion foi oficialmente lançada pelo PTB paranaense, que, ao mesmo tempo, deu início à uma sistemática campanha de oposição ao interventor Pinheiro Machado por meio de um jornal trabalhista denominado Diário Popular ${ }^{13}$.

Além dos vínculos com Lupion, outro fator que levou a deterioração das relações do PTB com Brasil Pinheiro Machado foi a exclusão dos trabalhistas da administração do Estado. Diante desse quadro, o PTB, em uma reunião realizada no dia 29 de abril de 1946, decidiu romper com Pinheiro Machado e lhe fazer oposição (Cf. Diário da Tarde, 3 maio 1946, p. 1).

No entanto, tal decisão catalisou uma grave crise interna, pois um grupo de petebistas não concordava com o rompimento do partido com o interventor e do apoio dado à candidatura de Lupion. Essa

12 Após a deposição de Getúlio Vargas (em 29 de outubro de 1945 por um golpe militar encabeçado por Dutra e Góes Monteiro), o interventor Manoel Ribas também foi deposto no início de novembro, passando o cargo de interventor do estado ao desembargador Clotário de Macedo Portugal, cuja principal missão era garantir as eleições de dezembro. Após as eleições de 1945, o interventor Clotário Portugal, considerando sua missão encerrada, decidiu exonerar-se do cargo. Em sua substituição, o recém-eleito presidente Dutra nomeou o pessedista Brasil Pinheiro Machado (advogado e professor da Universidade do Paraná) como o novo interventor paranaense.

13 Fundado no dia $1^{\circ}$ de maio de 1946 , o Diário Popular era impresso nas oficinas do jornal lupionista $O$ Dia e circulou de maio de 1946 até fevereiro de 1947, tendo como diretor Raul Viana, como gerente Abilon de Souza Naves e como secretário o jornalista Jorge Mathias Jr., todos membros do PTB paranaense e amigos de Lupion. Posteriormente, o jornal voltou a circular também por um período efêmero, entre abril e outubro de 1948, sendo novamente dirigido por Raul Viana e contando com Jorge Mathias Jr. (na função de diretor secretário) e Antônio dos Santos Filho (na função de diretor-gerente). 
fração do PTB alegava que o referido rompimento fora uma decisão somente do presidente Maximino Zanon e de alguns membros da Executiva Estadual, que a tomaram sem consultar os diretórios municipais do interior do estado (Cf. Diário da Tarde, 13 jun. 1946, p. 1).

A crise no partido acentuou-se ainda mais no final de maio de 1946, com a expulsão ${ }^{14}$ dos petebistas contrários com o rompimento com o interventor Pinheiro Machado, configurando a primeira grande cisão dentro do partido.

Em meio à crise, no início de junho de 1946, Maximino Zanon foi reeleito presidente do PTB paranaense durante a Convenção Estadual, que também elegeu a nova Executiva Estadual ${ }^{15}$ e o novo Diretório do partido, que, após a série de expurgos, sofreu uma significativa mudança, sobretudo pelo fato de muitos dos novos integrantes possuírem algum tipo de vínculo (amizade e/ou clientelístico) com Moysés Lupion, o que contribuiu para o processo de "lupionização" do PTB paranaense.

A referida Convenção marcou também a ascensão de Abilon de Souza Naves nas hostes trabalhistas, no posto de vice-presidente, em virtude, sobretudo, dos seus vínculos pessoais com Moysés Lupion $^{16}$ (convém lembrar que Souza Naves era gerente do jornal Diário Popular, órgão trabalhista financiado por Lupion).

14 Foram expulsos vários membros que tiveram importante atuação na fundação do PTB do Paraná. Dentre os expurgados estavam, entre outros, Milton Viana, que teve uma destacada atuação na organização da UTP e do PTB, além dos líderes sindicais Theodorico Ferreira Martins, Alfredo Santana Ribeiro e Sinibaldo Trombini, que, inclusive, concorreram nas eleições de dezembro de 1945 como candidatos do partido. Também foram expulsos José de Moura Filho (tesoureiro do partido), José Barbosa de Almeida (do conselho fiscal), Epaminondas Camargo, Elpídio Borba, José Nazareth Riceti, Normando Jusi, João Krack Neto, Otelo Lopes, Lourival Cardoso, Ernesto Saboia e Peni Withers Rodbacker.

15 A Executiva do PTB do Paraná ficou assim constituída: presidente de honra: Lúcio de Freitas (líder sindical); presidente: Maximino Zanon (líder sindical); vice-presidente: Abilon de Souza Naves (contador e funcionário público); primeiro secretário: Raul Viana (advogado); segundo secretário: Leonel Prado Martins (advogado); terceiro secretário: João Tavares Santana (líder ferroviário); primeiro tesoureiro: Adélio Ramiro de Assis (contador); segundo tesoureiro: Miguel Raitani; conselho fiscal: Bernardino Fialho Sobrinho (líder sindical), Rubens de Mello Braga (comerciante e ex-líder sindical) e José Joaquim Bertolini (líder sindical) (Cf. Diário Popular, 12 jun. 1946, p. 3).

16 De acordo com o depoimento de David Wille Lupion, Souza Naves tornou-se amigo de Lupion por meio de um amigo em comum: Raul Vaz, com quem trabalhava no IAPC (Apud SALLES, 2004, p. 98). 
Portanto, não restam dúvidas de que Maximino Zanon, Souza Naves e outros integrantes da cúpula do PTB paranaense possuíssem fortes vínculos com Moysés Lupion, que injetava dinheiro no partido $^{17}$ e patrocinava um jornal trabalhista que defendia explicitamente a sua candidatura, ao mesmo tempo em que atacava o seu principal concorrente, o interventor Pinheiro Machado.

\section{O governo Lupion, as crises político-partidárias e o "grande cisma" do PTB paranaense}

Combatido pelo PTB e dentro do seu próprio partido, o PSD, o clima político no Paraná tornou-se insustentável para o interventor Pinheiro Machado, que acabou renunciando e sendo substituído pelo Tenente Coronel Mário Gomes da Silva, em outubro de 1946. O novo interventor, que contava com o apoio do $\mathrm{PTB}^{18}$, adotou um discurso de pacificar a política paranaense e garantir a idoneidade das eleições estaduais de janeiro de 1947.

À medida que se aproximavam as eleições, a ala lupionista do PSD articulou uma grande coalizão interpartidária com o PTB que possuía um Diretório amplamente lupionista -, a UDN e o Partido de Representação Popular (PRP). Oficializado candidato pela coligação PSD-PTB-UDN-PRP, Moysés Lupion enfrentaria nas urnas Bento Munhoz da Rocha Neto, do $\mathrm{PR}^{19}$, que recebeu o apoio dos

17 A informação de que Lupion financiava as despesas do PTB do Paraná foram amplamente divulgadas pela imprensa curitibana e não foi desmentida por nenhum dirigente trabalhista.

$18 \mathrm{O}$ interventor Mário Gomes dividiu algumas secretárias para o PTB e a UDN, mas excluiu o Partido Republicano (PR), que era simpático ao ex-interventor Pinheiro Machado. Em particular, o PTB recebeu a Secretaria de Agricultura, Indústria e Comércio, que ficou com Raul Viana, então primeiro secretário do partido e diretor do jornal "trabalhista" Diário Popular.

19 Fruto de uma cisão udenista, o Partido Republicano foi reorganizado no Paraná no primeiro semestre de 1946 e tinha como um dos principais expoentes o deputado federal Bento Munhoz da Rocha Neto, que fora eleito pela própria UDN. 
dissidentes udenistas que não compactuaram com a aliança com o PTB e o PSD.

Todavia, a candidatura de Lupion era praticamente invencível, pois contava com o apoio oficial dos três principais partidos e dispunha de muitos recursos financeiros (COSTA, 1994, p. 366). Com o seu nome sendo propagandeado em todo o estado por meio de rádios e jornais de grande circulação ( $O$ Dia e a Gazeta do Povo), Lupion dizia-se representar a renovação - uma vez que não pertencia às famílias tradicionais, ao contrário de Bento Munhoz da Rocha Neto ${ }^{20}$. Utilizando-se de um discurso popular (cujo slogan era "Paraná maior"), prometeu apoiar as cidades e os interesses do interior do Paraná (MAGALHÃES, 2001, p. 56), enquanto Munhoz da Rocha era representado como um candidato das elites curitibanas. Assim, Lupion viu crescer a sua popularidade e venceu as eleições de 19 de janeiro de 1947 com 59,1\% dos votos, enquanto Munhoz da Rocha obteve 29,3\% dos votos (IPARDES, 1989, p. 11).

Para o Senado, o udenista Arthur Ferreira dos Santos (que contava com o apoio do PSD, do PTB e do PRP) derrotou o jornalista Roberto Barrozo $^{21}$ (PSP). No que tange à Assembléia Legislativa do estado, o PSD sagrou-se o grande vitorioso, elegendo 16 deputados, enquanto a UDN elegeu sete, o PTB $^{22}$ seis, o PR quatro, o PRP dois, o PSP um e o PCB também um (IPARDES, 1989, p. 122). Dessa forma, Moysés Lupion pôde, inicialmente, governar o Paraná com a maioria absoluta do Legislativo estadual, pois a grande coalizão interpartidária aglutinou $83,7 \%$ dos deputados.

Inicialmente, Lupion montou seu secretariado visando a contemplar os partidos que formaram a grande coalizão que o elegeu,

20 Bento Munhoz da Rocha Neto era filho de Caetano Munhoz da Rocha (que governou o Paraná entre 1920-1928) e era considerado o herdeiro político das velhas oligarquias destronadas após a Revolução de 1930 - que retornaram à política no pós-1945 concentrando-se na UDN e, em menor número, no PR.

21 O jornalista e advogado Roberto Barrozo foi um dos principais líderes queremistas do Paraná. Porém, não teve espaço dentro do PTB, sobretudo a partir da lupionização do partido. À frente do Diário da Tarde, Roberto Barrozo notabilizou-se pelos ferrenhos e constantes ataques a Moysés Lupion, a quem considerava seu inimigo político. Preterido da lista de candidatos petebistas, concorreu ao Senado em 1947 pelo PSP.

22 Por sua vez, o PTB elegeu, em ordem de votação, os seguintes deputados estaduais: Aldo Silva, Aldo Laval, Antônio dos Santos Filho, Julio Rocha Xavier, José Machuca e José Darú. 
dividindo as principais secretarias entre o PSD e a UDN (COSTA, 1994, p. 368). Entretanto, assim que se iniciaram os trabalhos na Assembleia Constituinte paranaense, em março de 1946, os pessedistas passaram a atacar a aliança com a UDN com o objetivo de se estabelecerem sozinhos no governo (COSTA, 1994, p. 369-370), ao mesmo tempo em que a imprensa pessedista - Gazeta do Povo e $O$ Dia - diariamente anunciavam que o rompimento era eminente, inclusive pressionando o udenista Major Francisco de Paula Soares, "por dever moral", a exonerar-se da pasta da Fazenda. No final de 1947, a crise entre os dois partidos acentuou-se e o iminente rompimento foi oficializado no início de 1948. A partir de então a UDN empreendeu uma ferrenha oposição ao governo Lupion, tornando-se uma implacável e eterna inimiga do governador paranaense.

Internamente, o PSD também entrou em ebulição. De um lado, estavam os deputados lupionistas; de outro, um grupo de deputados rebeldes, que ficaram conhecidos como "granadeiros 23 ", que criticavam abertamente o governador.

Por sua vez, o PTB paranaense também estava em efervescência com a divisão do partido em duas alas (lupionistas e antilupionistas), que disputaram o controle partidário durante a Convenção Estadual de $1^{\circ}$ de outubro de 1947. O tenso conclave, vencido pelos lupionistas, ficou marcado pela reeleição de Maximino Zanon e por uma significativa renovação na Executiva ${ }^{24}$ do partido (dos 11 antigos integrantes apenas cinco permaneceram). Verificava-

23 Os quatro deputados "granadeiros" eram Oscar Lopes Munhoz, Pedro Firman Neto, Alfredo Pinheiro Jr. e Francisco Acioli Filho. O termo "granadeiro" é uma alusão aos arremessadores de granadas explosivas.

24 A nova Comissão Executiva do partido ficou assim constituída: presidente: Maximino Zanon (ex-sindicalista e oficial do Cartório de Registro de Imóveis em Curitiba); vicepresidente: Abilon de Souza Naves (contador e funcionário público em Curitiba); secretário geral: Júlio da Rocha Xavier (deputado estadual e advogado com atuação em Curitiba); primeiro secretário: Reginaldo Cavalcanti (funcionário público em Curitiba); segundo secretário: Leonel Prado Martins (advogado com atuação em Curitiba); tesoureiro geral: Rene Varumbi de Paula; primeiro tesoureiro: José Machuca (deputado estadual e advogado com atuação em Curitiba e Antonina); segundo tesoureiro: Divonsir Borba Cortes (advogado com atuação em Londrina); conselho fiscal: Raul Viana (juiz do Tribunal de Contas em Curitiba), José Joaquim Bertolini (líder sindical em Curitiba) e Antonio Chalbaud Biscaia (advogado com atuação em Curitiba) (Cf. Diário da Tarde, 2 out. 1947, p. 6). 
se assim, a exemplo do que ocorria na Executiva Nacional - um processo de "elitização" do partido, com o ingresso de inúmeros políticos profissionais, empresários e profissionais liberais sobretudo advogados e funcionários públicos, especialmente os ligados aos órgãos do Ministério do Trabalho - o que culminou no afastamento dos sindicalistas dos postos de mando da agremiação. Portanto, a nova Executiva Estadual do PTB paranaense evidenciou o alijamento da ala "sindicalista" e o domínio dos "pragmáticosgetulistas 25 " nos postos de mando do partido.

Por meio do Diário da Tarde, o jornalista Roberto Barrozo, que havia retornado ao PTB e foi derrotado na convenção, denunciou o que ele chamou de "golpe dentro do PTB patrocinado por elementos do governo do Estado infiltrados no partido". Segundo Barrozo, Maximino Zanon, que recebera um cartório de registro de imóveis do governo Lupion, foi pressionado pelo governador a vencer as eleições a qualquer custo, sob a ameaça de perder o cartório para o filho do deputado Guataçara Borba Carneiro (PSD), líder do governo no Legislativo (Cf. Diário da Tarde, 2 out. 1947, p. 1 e 6).

De fato, Lupion tinha o máximo interesse que Maximino Zanon se reelegesse presidente do PTB paranaense e, assim, mantivessem o partido ao seu lado. Pois, do contrário, a vitória da chapa de Barrozo provavelmente representaria o afastamento do PTB do governador, que, inclusive, poderia passar a enfrentar sérias dificuldades na Assembléia Legislativa - pois as relações com a UDN caminhavam para o rompimento e, além disso, havia quatro

25 De acordo com Lucília de Almeida Neves Delgado (2001, p. 177-178), havia três principais tendências políticas dentro do PTB: $1^{\circ}$ ) Os "getulistas pragmáticos", conformados por burocratas vinculados à estrutura do Estado através do Ministério do Trabalho e por sindicalistas ligados ao corporativismo sindical oficial. Sua hegemonia no partido data dos primeiros anos de atuação do PTB, se estendendo de 1945 até, mais ou menos, 1954. Sua principal referência foi o próprio Getúlio Vargas. $2^{\circ}$ ) Os "doutrinários trabalhistas", que eram os intelectuais orgânicos do petebismo e se inscreviam em uma orientação trabalhista socializante, que propugnava uma maior desvinculação do partido em relação ao Estado. Sua influência no partido começou em torno de 1948, com Alberto Pasqualini, e se estendeu até a década de 1960, com Sérgio Magalhães e San Tiago Dantas. $3^{\circ}$ ) Os "pragmáticos reformistas", que atuaram principalmente a partir da segunda metade dos anos 1950 e amalgamaram em sua prática político-partidária características da tendência getulista e da tendência doutrinária. Seu principal expoente foi João Goulart, porém outros petebistas também se destacaram como líderes desta tendência, como, Leonel Brizola. 
deputados pessedistas rebeldes (os "granadeiros") que poderiam encorpar ainda mais a oposição.

Para garantir a vitória na Convenção, a chapa de Maximino Zanon incorporou, de última hora, inúmeros petebistas do interior do estado no Diretório, com o objetivo de, por meio da cooptação, garantir votos para a sua chapa. Entretanto, essa manobra de Zanon acabou excluindo alguns influentes trabalhistas - que faziam parte do antigo Diretório - do novo Diretório Estadual do partido, como o deputado estadual Aldo Silva, o jornalista Jorge Mathias Jr. e os sindicalistas Bernardino Fialho Sobrinho e Ubiratan Peixoto de Matos, entre outros, que ameaçaram abrir uma dissidência nas hostes petebistas, organizando a formação de uma Ala Independente do PTB, que também contou com a adesão dos deputados petebistas José Darú e Aldo Laval (que, inclusive, pediram os seus respectivos afastamentos do Diretório Estadual), além dos líderes sindicais Lúcio de Freitas (ex-presidente de honra do PTB) e João Tavares Santana, entre outros (Cf. Diário da Tarde, 4 out. 1947, p. 6).

Contudo, a crise interna do PTB paranaense agravou-se ainda mais em 1948. Em 21 de janeiro, Roberto Barrozo, recém-eleito vereador mais votado em Curitiba pelo PTB, foi expulso do partido após se desentender com os outros vereadores petebistas e atacá-los veementemente em uma tensa sessão realizada no dia 20 de janeiro ${ }^{26}$.

Logo em seguida, no dia 22 de janeiro de 1948, o presidente do PTB paranaense, Maximino Zanon, faleceu. A partir de então, o claudicante partido, dirigido provisoriamente pelo vice-presidente Abilon de Souza Naves, atravessou um período de grande turbulência, cuja crise tornou-se ainda mais aguda em fevereiro de 1948, quando ocorreu uma grande dissidência nas hostes petebistas: inúmeros trabalhistas, incluindo cinco dos sete deputados estaduais do partido -

26 A causa principal da discórdia foi o fato do prefeito provisório nomeado de Curitiba, o petebista João Krack Neto, pleitear um significativo aumento dos impostos municipais. Barrozo, que na época era presidente da Câmara de Vereadores da capital, era contrário ao aumento dos impostos e insinuou que a bancada de vereadores petebistas teria recebido uma quantia em dinheiro para votar em favor do referido aumento (Cf. "Rompeu com o PTB para ficar com o povo". In: Diário da Tarde, 21 jan. 1948, p. 6). 
Antônio dos Santos Filho, Aldo Laval, Aldo Silva, José Darú e Júlio Buskei $^{27}$ migraram para o PSD ${ }^{28}$.

Embora os dissidentes alegassem desentendimentos com a Executiva do partido, há fortes indícios de que o real motivo para a cisão no PTB tenha sido fomentado pelo governador Lupion e pelo PSD, que cooptou os mencionados deputados estaduais e outros influentes petebistas, excluídos das posições de mando do partido, para compensar a rebeldia dos deputados granadeiros (Cf. Diário da Tarde, 13 fev. 1948, p. 1 e 6). Em outras palavras, o PSD, que já havia rompido com a UDN, planejou cooptar os deputados trabalhistas para garantir a maioria no Legislativo e, assim, romper com o PTB e governar o Paraná sozinho, como era a vontade de alguns influentes pessedistas.

Após estimular a dissidência dentro do PTB, o governador Lupion e o PSD trataram de colocar os petebistas à margem do governo estadual. A partir de então, as relações entre o PTB paranaense e o governador se deterioraram e, gradativamente, os petebistas passaram a fazer oposição a Lupion, cujo rompimento foi oficializado, em setembro de 1948, por meio de um manifesto. Portanto, após lançar a candidatura de Lupion e a apoiá-la incondicionalmente, o PTB paranaense rompeu com o governador, "acusando-o de ingrato, traidor e de querer destruir o partido".

\section{A ascensão de Souza Naves à presidência do PTB paranaense}

Após o rompimento com o governador paranaense, o PTB do Paraná passou por um período de grande disputa interna pelos altos

27 Júlio Buskei havido sido eleito pelo PRP, mas migrou para o PTB em 1947.

28 Além dos deputados acima mencionados, também migraram para o Departamento Trabalhista do PSD os seguintes petebistas: Lúcio de Freitas, João Tavares Santana, Raul Viana, Jorge Mathias Jr., Antonio Chalbaud Biscaia, Saturnino Fernandes, entre outros, que lançaram um manifesto político, datado de 20 de fevereiro de 1948, explicando as razões dos seus respectivos desligamentos do PTB (Cf."Manifesto Político". O Dia, 22 fev. 1948, p. 1; Gazeta do Povo, 22 fev. 1948, p. 1 e 6). 
escalões do partido. Na Convenção Estadual, realizada no dia 16 de outubro de 1949 e que contou com a presença de Salgado Filho então presidente nacional do partido ${ }^{29}-$, concorreram dois grupos: de um lado, a chapa de Abilon de Souza Naves (então presidente provisório do partido); de outro, a chapa de Francisco Souza Neto (presidente do Diretório Municipal de Ponta Grossa).

Apesar dos constantes ataques de Roberto Barrozo, Abilon de Souza Naves (acusado de "lupionista" pelo jornalista do Diário da Tarde) venceu a disputa e elegeu-se o novo presidente do PTB paranaense, cuja Comissão Executiva ${ }^{30}$ sofreu uma grande renovação, com a permanência de apenas três membros da antiga Executiva ${ }^{31}$. Dentre os novos integrantes da Executiva Estadual, merece destaque a ascensão de Parahylio Borba, que assumiu o posto de primeiro vicepresidente do partido, e o ingresso do deputado federal Rubens de Mello Braga, um dos fundadores do PTB paranaense, no recémcriado posto de segundo vice-presidente.

Após a Convenção Estadual do PTB do Paraná, vários integrantes da chapa derrotada lamentaram "que o partido continuasse sendo dirigido por pessoas ligadas a Lupion" e optaram em se desligar do PTB - como Leonel Prado Martins (que integrava a antiga Comissão Executiva), Manoel Quadrado, Mário Santana Lobo,

29 Salgado Filho assumiu a presidência nacional do PTB em meados de junho de 1948 com o objetivo de reestruturar e, sobretudo, pacificar internamente o PTB.

30 A nova Comissão Executiva ficou assim constituída: presidente de honra: Getúlio Vargas; presidente: Abilon de Souza Naves (contador e funcionário público em Curitiba); primeiro vice-presidente: Parahylio Borba (advogado com atuação em Santo Antônio da Platina); segundo vice-presidente: Rubens de Mello Braga (deputado federal, comerciante e produtor rural em Curitiba); secretário geral: Júlio Rocha Xavier (deputado estadual e advogado com atuação em Curitiba); primeiro secretário: José Machuca (deputado estadual e advogado com atuação em Curitiba e Antonina); segundo secretário: Alexandre Zainko (engenheiro químico com atuação em Curitiba); tesoureiro geral: Emanoel Coelho (advogado com atuação em Curitiba); primeiro tesoureiro: José Campelli Filho (dentista com atuação em Curitiba); segundo tesoureiro: Elias Defune (do diretório de Cambará); conselho fiscal: Ignácio Iguaçu Franco (líder sindical em Curitiba), Antônio Baby (ferroviário em União da Vitória) e Dilo de Oliveira Godói (líder sindical em Curitiba) (Gazeta do Povo, 18 out. 1949, p. 8).

31 Além de Abilon de Souza Naves (eleito presidente do partido), o deputado estadual Júlio Rocha Xavier foi mantido no posto de secretário geral, enquanto o deputado estadual José Machuca foi remanejado de primeiro tesoureiro para primeiro secretário. 
Roberto Barrozo Filho, entre outros ${ }^{32}$. Enfim, como se pode perceber, a pacificação interna do PTB paranaense ainda estava muito distante de se concretizar.

Liderado por Abilon de Souza Naves, o PTB do Paraná encontrava-se, no final da década de 1940, bastante enfraquecido tanto estruturalmente quanto financeiramente. Assim, nos anos seguintes, reestruturar o partido e fortalecê-lo tornou-se uma importante tarefa para Souza Naves.

Para tais propósitos, Souza Naves inicialmente procurou seguir as orientações do Diretório Nacional no sentido de pacificar e reestruturar o partido. Desta maneira, optou em não reatar as relações entre os petebistas e Lupion e adotar uma posição neutra da sucessão estadual de 1950, vencida pelo candidato antilupionista Bento Munhoz da Rocha Neto (PR), que derrotou o candidato lupionista Angelo Lopes (PSD) ${ }^{33}$.

Nas eleições ao Senado, o PSD paranaense sofreu mais uma derrota: Raul Vaz, amigo íntimo de Lupion, perdeu a eleição para o udenista Othon Mader, um dos principais adversários políticos do governador paranaense ${ }^{34}$. Por sua vez, o PTB paranaense optou em abster-se das eleições para a senadoria, não concorrendo com candidato próprio e não apoiando oficialmente nenhum candidato.

No que tange à Câmara dos Deputados, houve um grande equilíbrio: o PSD elegeu três deputados; o PTB ${ }^{35}$ também três e a

32 Em meados de novembro de 1949, esses dissidentes petebistas reorganizaram no Paraná o Partido Social Trabalhista (PST), que então atravessava um período de instabilidade. Em seguida, o PST paranaense elegeu uma nova Comissão Executiva Estadual, cuja presidência ficou com Roberto Barrozo (Cf. "Constituído o novo Diretório Estadual do Paraná do PST". In: Diário da Tarde, 29 nov. 1949 , p. 1).

33 Nas eleições de 3 de outubro de 1950, Bento Munhoz da Rocha Neto obteve 62,9\% dos votos, enquanto Angelo Lopes conquistou 30,7\% dos votos e Carlos Amoreti Osório (PSB) apenas $0,1 \%$ (IPARDES, 1989, p. 11). Além da campanha moralista, a esmagadora vitória de Munhoz da Rocha deve-se principalmente à união das forças antilupionistas, que aglutinou diversos partidos (como o PR, a UDN, o PRP, o PL e o PST), além de uma significativa fração do PTB e de uma ala dissidente do PSD (capitaneada pelo Major Fernando Flores e por Aramis Athayde cunhado de Munhoz da Rocha).

34 Dessa forma, Othon Mader substituiria o também udenista Arthur Ferreira dos Santos (eleito em 1947) e se juntaria aos pessedistas Flávio Guimarães e Roberto Glaser (eleitos em 1945) na senatoria paranaense.

35 O PTB do Paraná, além de reeleger Rubens de Mello Braga, conquistou mais duas cadeiras, com os advogados Parahylio Borba e Sebastião Vieira Lins. 
coligação UDN/PR/PST/PRP/PL igualmente três. Na Assembleia Legislativa, por sua vez, embora o PSD tenha conquistado 16 cadeiras, o grande vencedor foi o $\mathrm{PTB}^{36}$, que elegeu 12 deputados (o dobro da eleição anterior) ${ }^{37}$. Quanto aos demais partidos, a UDN conquistou oito cadeiras, o PR seis, o PSP duas e o PRP uma cadeira.

Portanto, o PTB paranaense, apesar de enfrentar problemas estruturais e financeiros, apresentou um significativo crescimento eleitoral graças, sobretudo, à força simbólica do getulismo e da doutrina trabalhista, cujo poder de mobilização política e social foi uma estratégia amplamente utilizada pelos candidatos petebistas. Assim, o partido elegeu três deputados federais e doze deputados estaduais, que representavam diversas cidades do interior do estado, evidenciando que, sob o comando de Souza Naves, o PTB estava gradativamente se estruturando e crescendo no interior do Paraná.

\section{As disputas pelo poder e a consolidação da liderança de Abilon de Souza Naves no PTB do Paraná}

No início de 1951, o recém empossado governador Bento Munhoz da Rocha Neto deu início às conversações com o PTB paranaense, que passou a exigir inúmeras secretarias e nomeações. Como as pastas e os cargos oferecidos pelo governo estadual não eram os desejados pelos petebistas, as negociações entre Bento e o PTB tornaram-se longas e difíceis.

O deputado federal Parahylio Borba (primeiro vicepresidente do PTB paranaense), Estevam Ribeiro de Souza Neto e

36 Para a Assembleia Legislativa, o PTB elegeu, em ordem de mais votados, os seguintes deputados: Raul de Rezende Filho, Júlio Rocha Xavier, José Hoffmann, Dagoberto Pusch, Antônio Baby, Alcides Caetano, Francisco Silveira Rocha, Antônio Annibelli, Gastão Vieira de Alencar, Francisco Soares, Divonsir Borba Cortes e Jorge de Lima.

37 Contudo, convém lembrar que o crescimento eleitoral do PTB não significou um jogo de soma zero, isto é, não houve uma simples transferência das cadeiras udenistas e pessedistas para os petebistas, uma vez que houve um aumento do número de cadeiras - de 37, em 1947, para 45, em 1950. 
Wallace Tadeu de Mello e Silva ${ }^{38}$ (ambos do diretório de Curitiba) possuíam estreitos vínculos com Bento e defendiam a imediata aliança do partido com o governador. Como a "orientação pragmática" empreendida por Souza Naves estava dificultando a coalizão, planejaram uma manobra para destituí-lo da presidência do partido.

Assim, no início de março de 1951, Parahylio Borba convenceu alguns membros da Executiva Estadual a renunciarem aos seus cargos e solicitarem a intervenção de Danton Coelho ${ }^{39}$, então presidente nacional do partido, no PTB paranaense (Gazeta do Povo, 8 mar. 1951, p. 1). A manobra foi bem sucedida e o Diretório Nacional interveio na seção paranaense, afastando a Executiva Estadual e nomeando, em 13 de maio de 1951, uma "comissão de reestruturação partidária" presidida por Estevam Ribeiro de Souza Neto e composta por Parahylio Borba e Wallace Tadeu de Mello e Silva.

Desse modo, se configurou uma luta interna no PTB paranaense pela direção partidária: de um lado, o grupo de Abilon de Souza Naves; de outro, o grupo de Estevam Ribeiro de Souza Neto e Parahylio Borba. Essa situação propiciou mais uma aguda crise no PTB do Paraná, cindindo o partido entre os membros da Executiva Estadual destituída (da qual integravam vários parlamentares federais e estaduais) e a comissão de reestruturação partidária.

Contudo, após a queda de Danton Coelho da presidência nacional do PTB e da pasta do Trabalho ${ }^{40}$, a comissão de reestruturação foi perdendo força dentro das hostes petebistas e na Convenção Estadual do partido, realizada nos dias 8 e 9 de setembro

38 Wallace Tadeu de Mello e Silva é pai de Roberto Requião de Mello e Silva, governador do Paraná entre os anos de 1991-1994 e 2003-2010.

39 Danton Coelho assumiu a presidência nacional do PTB por imposição de Vargas em agosto de 1950 - após a morte de Salgado Filho -, em uma manobra que visava somente às eleições presidenciais e não à organização partidária e que foi recebida com reservas por alguns grupos dentro do partido (Cf. D’ARAÚJO, 1996, p. 54-57).

40 Sem o apoio irrestrito de Vargas às atividades de seu ministério e insatisfeito com a política conciliatória do presidente, que cortejava a UDN, além de enfrentar uma forte oposição nas hostes petebistas, sobretudo a liderada por Ivete Vargas no PTB paulista, Danton renunciou à presidência do partido em junho de 1951. Em setembro do mesmo ano também deixou o Ministério do Trabalho, sendo substituído por Segadas Viana (DELGADO, 1989, p. 111-112). 
de 1951, e que contou com a importante intermediação de Dinarte Dornelles, então presidente da Executiva Nacional ${ }^{41}$, Abilon de Souza Naves derrotou Parahylio Borba e foi reconduzido à presidência estadual do partido, cuja nova Comissão Executiva ${ }^{42}$ foi amplamente renovada com a inclusão de dez novos membros e a permanência de apenas quatro membros (Júlio Rocha Xavier, José Machuca, Rubens de Mello Braga e Antônio Baby) da antiga cúpula partidária.

Nesse sentido, convém observar que a maior parte desses novos dirigentes eram deputados estaduais e representavam vários diretórios do interior do Paraná, ao contrário da Executiva eleita em 1949, composta quase exclusivamente por representantes do Diretório de Curitiba. Dessa forma, percebe-se a articulação política tecida por Souza Naves com os diretórios do interior do estado, que foi fundamental para angariar o apoio necessário para reconquistar a presidência do partido.

Assim, após quatro meses afastados dos postos de comando do PTB paranaense, Souza Naves e alguns membros da antiga cúpula partidária retornaram ao comando do partido, que se encontrava ainda longe de um consenso acerca da posição que tomaria durante o governo de Bento Munhoz da Rocha Neto, que voltou a cortejar

41 Segundo Lucília Delgado (1989, p. 112-113), a eleição de Dinarte Dornelles, primo de Getúlio e profundamente vinculado a grupo de Ivete Vargas em São Paulo - que representava a ala mais fisiológica do PTB -, não significou um apaziguamento do partido, pois os partidários de Danton Coelho passaram a adotar atitudes de forte hostilidade ao novo presidente do partido.

42 A nova Comissão Executiva do PTB ficou assim constituída: presidente de honra: Getúlio Vargas; presidente: Abilon de Souza Naves; primeiro vice-presidente: Cel. Sílvio Van Erven Jr. (militar com atuação em Curitiba); segundo vice-presidente: Gastão Vieira de Alencar (deputado estadual e funcionário público em Cornélio Procópio); terceiro vice-presidente: Júlio Rocha Xavier (deputado estadual e advogado com atuação em Curitiba); secretário geral: José Hoffmann (deputado estadual e jornalista em Ponta Grossa); primeiro secretário: Jorge de Lima (deputado estadual e promotor público em Siqueira Campos); segundo secretário: Antônio Annibelli (deputado estadual e advogado com atuação em Clevelândia); terceiro secretário: Divonsir Borba Cortes (deputado estadual e advogado com atuação em Londrina); tesoureiro geral: Raul de Rezende Filho (cafeicultor na região de Jacarezinho); primeiro tesoureiro: José Machuca (advogado com atuação em Curitiba e Antonina); segundo tesoureiro: Jacinto Cunha (radialista da Rádio Clube Paranaense, de Curitiba); terceiro tesoureiro: Antônio Baby (deputado estadual e líder ferroviário em União da Vitória); conselho fiscal: Rubens de Mello Braga (deputado federal, comerciante e produtor rural na região em Curitiba); Sebastião Vieira Lins (deputado federal, advogado e jornalista com atuação em São Paulo e Curitiba) e Myltho Anselmo da Silva (vereador e funcionário público em Curitiba) (Cf. Gazeta do Povo, 11 set. 1951, p. 8). 
sistematicamente o $\mathrm{PTB}^{43}$, inclusive nomeando Souza Naves para a recém-inaugurada Secretária do Trabalho e Assistência Social ${ }^{44}$.

No entanto, a relação entre o PTB paranaense e o governador Munhoz da Rocha foi repleta de nuanças, com períodos de relativa cumplicidade e outros de discordâncias e desentendimentos. Na verdade, adotando uma posição pragmática, o PTB paranaense revelou-se um partido sem uma posição oficial bem definida e, assim, dividiu-se em duas alas: uma bentista, que barganhava apoio político em troca de cargos e nomeações; e uma que defendia a "independência" do PTB, isto é, sem nenhum tipo de compromisso oficial com o Executivo estadual.

Sentindo-se desprestigiados, uma vez que o PTB ocupava uma posição periférica no governo ${ }^{45}$, os "independentes", a partir de 1952, ganharam força dentro do partido. Argumentando que "o PTB não poderia apenas servir de escada para outros políticos e partidos", defendiam uma posição neutra junto ao governo Bento visando ao crescimento do partido para as eleições estaduais de 1955, na qual os trabalhistas planejavam concorrer com candidato próprio (Cf. Gazeta do Povo, 7 jun. 1952, p. 3).

Ainda em 1952, ascendeu dentro do PTB do Paraná um grupo de "independentes" progressistas que se manifestavam por meio de um jornal semanário próprio, a Vanguarda Trabalhista, dirigida pelo jornalista Gamaliel Bueno Galvão e pelo estudante de Direito Manoel Claudius Gomes Pereira, então presidente da Mocidade Trabalhista do Paraná, uma ala jovem do PTB paranaense.

43 Sem dúvida, conquistar o apoio do PTB era importante para o governo Bento Munhoz da Rocha Neto, que enfrentava a oposição sistemática do PSD, partido majoritário na Assembleia e que dominava a grande imprensa paranaense.

44 Abilon de Souza Naves assumiu a secretaria em setembro de 1951, ficando na pasta até abril de 1952. Após a saída de Souza Naves, ocuparam a pasta, em ordem cronológica, Cel. Alcides Amaral Barcellos, Jorge de Lima, Estevam de Souza Neto e novamente o Cel. Alcides do Amaral Barcellos. Portanto, esta pasta tradicionalmente ficava com o PTB, que esporadicamente também ficava com alguma outra secretaria (caso do deputado federal Rubens de Mello Braga, que ocupou a Secretaria da Agricultura). As demais secretarias estiveram com o PR e a UDN e eventualmente com algum pessedista da ala antilupionista.

45 Muitos petebistas estavam descontentes com o governador pelo fato das principais posições de mando do governo estar nas mãos do perrepistas e dos udenistas, enquanto os trabalhistas ficavam tradicionalmente com a pasta do Trabalho e Assistência Social e eventualmente com outra secretaria periférica. 
Gamaliel Bueno Galvão e os jovens Manoel Claudius Gomes Pereira e Léo de Almeida Neves (também estudante de Direito e vicepresidente da Mocidade Trabalhista do Paraná) representavam o grupo dos "pragmáticos reformistas", neste momento ainda uma tendência minoritária dentro do PTB do Paraná ${ }^{46}$.

Os "pragmáticos reformistas", que ganharam destaque dentro do partido a partir da segunda metade dos anos 1950, defendiam um programa nacionalista e reformista e sua prática político-partidária era um amálgama da tendência "pragmático getulista" e da tendência "doutrinário trabalhista" (DELGADO, 2001, p. 177-178). Seu principal expoente foi João Goulart, que ascendeu à presidência nacional do PTB na VI Convenção Nacional do partido, realizada em 20 de maio de $1952^{47}$. A ascensão de Jango - o "ungido de Vargas" significou um marco na história do PTB, pois o novo presidente empreenderia uma nova linha de ação, nacionalista e reformista, que se consolidaria ao longo da história do partido.

No mesmo conclave que elencou João Goulart à presidência do PTB, Abilon de Souza Naves também passou a integrar a Executiva Nacional do partido como quarto vice-presidente. A partir de então, Souza Naves aproximou-se de Jango, de quem se tornou um fiel aliado, tornando-se, a partir da Convenção Nacional de julho de 1953, o segundo vice-presidente nacional do PTB. Portanto, os vínculos que possuía com Getúlio Vargas e João Goulart foram fundamentais para que Souza Naves ascendesse à Executiva Nacional e consolidasse a sua liderança no PTB paranaense durante a década de 1950.

Na Convenção Estadual do PTB paranaense, marcada para 13 de setembro de 1953, Abilon de Souza Naves disputaria novamente a presidência do partido com o deputado federal Parahylio Borba. Entretanto, possuindo vínculos com Vargas e Jango e gozando de

46 Getulistas e admiradores de Alberto Pasqualini, esse grupo buscou expressar as suas ideias por meio de alguns periódicos de efêmera duração, como O Petebê (1950), Jornal Trabalhista (1950), Vanguarda Trabalhista (1952) e O Petebista (1952).

47 A indicação do jovem parlamentar sul-rio-grandense João Goulart à presidência do PTB - em substituição a Dinarte Dornelles, que sofria forte oposição da maioria dos petebistas, que exigiam a sua substituição - foi uma medida conciliatória de Getúlio Vargas, que tentava apaziguar o partido (D’ARAÚJO, 1996, p. 90-91). 
grande prestígio nas hostes trabalhistas, inclusive integrando a Executiva Nacional do partido, Souza Naves venceu facilmente a disputa e foi reeleito presidente do partido ${ }^{48}$, cuja Comissão Executiva $^{49}$ sofreu uma renovação de $50 \%$, com o ingresso de oito novos dirigentes, que substituíram importantes nomes da antiga Executiva que haviam rompido com Souza Naves, como os deputados federais Rubens de Mello Braga e Sebastião Vieira Lins e os deputados estaduais Júlio Rocha Xavier, José Hoffmann e Jorge de Lima.

Repetindo a estratégia utilizada na Convenção anterior, Souza Naves procurou integrar à Executiva Estadual representantes de quase todas as regiões do Paraná, com o objetivo de aumentar a sua rede de relações e influência política. Portanto, além de consolidar a sua liderança no PTB paranaense, Souza Naves também articulou uma rede social de relações de amplo alcance, uma vez que os membros da Executiva Estadual oriundos do interior serviriam de "ponte ${ }^{50,}$ para as diversas regiões do Paraná.

48 Além de ser reeleito presidente do PTB paranaense, Souza Naves foi também nomeado, em setembro de 1953, por Getúlio Vargas presidente do Instituto de Previdência e Assistência aos Servidores do Estado (IPASE).

49 A nova Executiva do PTB paranaense ficou assim formada: presidente de honra: Getúlio Vargas; vice-presidente de honra: João Goulart; presidente: Abilon de Souza Naves; primeiro vice-presidente: José Machuca (advogado com atuação em Curitiba e Antonina); segundo vice-presidente: Gastão Vieira de Alencar (deputado estadual e funcionário público em Cornélio Procópio); terceiro vice-presidente: Pedro Mariucci (comerciante e prefeito de Cornélio Procópio); quarto vice-presidente: Jacinto Cunha (radialista da Rádio Clube Paranaense, de Curitiba); secretário geral: Alexandre Zainko (engenheiro químico em Curitiba); primeiro secretário: Raul de Rezende Filho (deputado estadual e cafeicultor na região de Jacarezinho); segundo secretário: Antônio Annibelli (deputado estadual e advogado em Clevelândia); terceiro secretário: Divonsir Borba Cortes (deputado estadual e advogado em Londrina); tesoureiro geral: Domício Scaramella (empresário madeireiro e prefeito de União da Vitória); primeiro tesoureiro: José Campelli Filho (dentista em Curitiba); segundo tesoureiro: Anizio Eunápio da Conceição (funcionário público em Cambará); terceiro tesoureiro: Francisco Silveira Rocha (farmacêutico em Marialva); conselho fiscal: Parahylio Borba (deputado federal e advogado em Santo Antônio da Platina), Estevam Ribeiro de Souza Neto (advogado em Curitiba) e Antônio Baby (deputado estadual e líder ferroviário em União da Vitória) (Diário da Tarde, 17 set. 1953, p. 6 e 4).

$50 \mathrm{O}$ conceito de ponte aqui utilizado é o proposto por Mark Granovetter (2000). De acordo com o autor (p.12-13), em uma rede social a "ponte" é uma espécie de intermediário entre diferentes indivíduos ou grupos sociais, que possibilita aos indivíduos acender a mundos que lhes estariam vedados no interior de sua rede de relações próximas. Segundo o autor (p. 45), em grandes redes as pontes significam que qualquer coisa que seja difundida pode chegar a um grande número de pessoas e atravessar uma grande distância social. 
Em suma, Souza Naves também procurou consolidar a sua liderança à frente do PTB do Paraná costurando alianças com diversos diretórios trabalhistas do interior do estado, o que foi fundamental para que vencesse as constantes disputas com Parahylio Borba pelo comando partidário. Portanto, além dos fortes vínculos pessoais que mantinha com Vargas e Jango, Souza Naves também se revelou um político astuto, conciliador e muito pragmático, o que contribuiu para a consolidação da sua liderança frente ao PTB paranaense.

\section{O rompimento com Bento Munhoz da Rocha Neto e as eleições de 1954 e 1955}

Na Convenção trabalhista de setembro de 1953 praticamente não se discutiu sobre a posição oficial do PTB no governo Bento Munhoz da Rocha Neto e, assim, o partido manteve a mesma postura equidistante e pragmática por mais alguns meses.

Contudo, nesse ínterim, cresceram os descontentamentos internos com a posição periférica ocupada pelo partido no governo estadual. Assim, alguns setores do PTB, sobretudo a "ala independente", passaram a defender o rompimento com o governador, oficializado em 4 de abril de 1954, quando o partido reuniu-se em uma Convenção para definir os seus candidatos nas eleições legislativas de outubro de 1954. Nesse encontro, que contou com a presença de João Goulart, presidente nacional do partido e agora exministro do Trabalho ${ }^{51}$, os "independentes" e demais favoráveis ao rompimento venceram por 69 votos contra 41 (Cf. Diário da Tarde, 5 abr. 1954, p. 1 e 6$)$.

51 Jango ocupou o Ministério do Trabalho do governo Vargas de julho de 1953 a fevereiro de 1954, quando uma crise política originada do seu projeto em aumentar em $100 \%$ o salário mínimo - que provocou uma grande revolta dos setores empresariais, militares (que lançaram o Manifesto dos Coronéis) e conservadores da sociedade - tornou a sua situação insustentável. 
Além da decisão de romper oficialmente com o governador Bento Munhoz da Rocha Neto, a Convenção de abril de 1954 também definiu os candidatos petebistas nas eleições para o Senado, a Câmara dos Deputados e a Assembleia Legislativa do Paraná, que seriam realizadas em outubro do mesmo ano. Entretanto, a maior disputa ocorreu pela definição do candidato trabalhista ao Senado, vaga essa cobiçada pelos deputados federais Sebastião Vieira Lins e Parahylio Borba, que venceu a queda de braço e tornou-se o candidato do PTB paranaense ao Senado.

Nas eleições de 3 de outubro de 1954, o suicídio de Getúlio Vargas - ocorrido cerca de 40 dias antes do pleito - não se tornou um fator decisivo de desequilíbrio a favor dos trabalhistas no Paraná. Na disputa ao Senado, o petebista Parahylio Borba foi derrotado pelo exgovernador Moysés Lupion e por Alô Guimarães, ambos do PSD. No que tange à Câmara dos Deputados, houve um equilíbrio entre os três principais partidos: o PSD elegeu quatro deputados, PTB $^{52}$ também quatro, a UDN três, o PR dois e o PSP um. Por sua vez, no legislativo estadual houve um grande equilíbrio entre o PTB ${ }^{53}$ e o PSD, com cada um dos partidos elegendo 11 deputados estaduais, enquanto a UDN elegeu oito, o PR e o PSP elegeram sete cada um e o emergente PDC elegeu um deputado - totalizando 45 deputados estaduais.

Além das eleições para o Legislativo federal e estadual, outro importante acontecimento político em 1954 foi a primeira eleição direta à prefeitura de Curitiba, também realizada em outubro, vencida pelo major Ney Braga ${ }^{54}$, que ascendia no cenário político paranaense.

Após as eleições de 3 de outubro de 1954, as atenções político-partidárias direcionaram-se para as sucessões presidencial e estadual. No Paraná, especulava-se que o governador Bento

52 O PTB elegeu para a Câmara dos Deputados os deputados estaduais Divonsir Borba Cortes e Antônio Baby, além de dois novos nomes que emergiram no partido: Cid Campello e Heitor Pereira Filho.

53 O PTB elegeu os seguintes deputados: Antônio Annibelli, Raul de Rezende Filho, Mário Batista de Barros, Jorge de Lima, Miguel Buffara, Domício Scaramella, José Teixeira da Silveira, Pedro Liberti, Pedro Mariucci, Joaquim Néia de Oliveira e Libâneo Estanislau Cardoso.

54 Embora não fosse filiado a nenhum partido, Ney Braga - que era ex-cunhado do então governador Bento Munhoz da Rocha Neto e ocupava o posto de Chefe de Polícia do Paraná desde 1952 - teve a sua candidatura à prefeitura de Curitiba lançada pelo governador paranaense e, dessa forma, contou com o apoio do PR e do PSP. 
renunciaria ao governo paranaense, uma vez que pretendia lançar-se como candidato à presidência da República em 1955. Entretanto, Bento renunciou em 3 de abril de 1955 não para concorrer às eleições de 1955, mas para assumir o Ministério da Agricultura no governo de João Café Filho, permanecendo no cargo até novembro de $1955^{55}$. Após a renúncia, o governo do Paraná esteve interinamente, durante o mês de abril, nas mãos do deputado petebista Antônio Annibelli, presidente da Assembleia Legislativa ${ }^{56}$, até que uma eleição indireta elegeu o banqueiro Adolpho de Oliveira Franco como o governador responsável para concluir o mandato de Bento.

Em âmbito nacional, o PTB discutia internamente a posição política a ser adotada nas eleições presidenciais de 1955. Neste sentido, os trabalhistas encontravam-se divididos em três grupos: "um minoritário, que defendia o lançamento de candidato próprio às eleições; outra que pensava em reviver a aliança PSP-PTB; e outra, da qual João Goulart era adepto, que pretendia a realização de uma aliança PTB-PSD" (DELGADO, 1989, p. 168). No dia 11 de abril de 1955, poucos dias antes da Convenção Nacional do PTB, realizou-se uma reunião na casa de Oswaldo Aranha - na qual estavam presentes os petebistas João Goulart, Abilon de Souza Naves (vice-presidente do PTB) e os líderes pessedistas Ernani do Amaral Peixoto e Juscelino Kubitschek -, acertando-se as bases do acordo eleitoral (DELGADO, 1989, p. 169). Posteriormente, a aliança foi homologada na Convenção Nacional do PTB, realizada em 18 de abril de 1955.

Em nível estadual, o PTB paranaense, desde 1951, já planejava concorrer à sucessão estadual com um candidato próprio, cujo nome mais provável era o de Abilon Souza Naves, presidente da Executiva Estadual. No entanto, Souza Naves, alegando motivos de saúde, anunciou que não pretendia mais concorrer ao governo do estado. A partir dessa reviravolta, o PTB paranaense passou a ser cortejado por diversos partidos, dentre eles a UDN e o PSD, além de

55 Em novembro de 1955, Café Filho precisou se afastar da presidência, sendo substituído por Carlos Luz e, em seguida, por Nereu Ramos.

$56 \mathrm{Na}$ época não havia o posto de vice-governador, que somente foi criado no início de 1964. 
também ter ocorrido uma grande disputa interna para o posto de candidato trabalhista.

Durante a Convenção Estadual do partido, realizada no dia 22 de maio de 1955, os principais nomes que despontavam como postulantes ao posto de candidato trabalhista eram Mário de Barros, Parahylio Borba e Rubens de Mello Braga. Contudo, apoiado por Souza Naves e contando com a simpatia de grande parte do Partido Republicano (PR), o médico e deputado estadual Mário de Barros, que então ocupava a secretaria de Saúde do governo de Adolpho de Oliveira Franco, venceu a disputa e foi oficializado como o candidato petebista ao governo do Paraná (Diário da Tarde, 23 maio 1955, p. $1)$.

Nos meses seguintes, os demais partidos foram definindo os seus candidatos à sucessão estadual: o PSD lançou o nome do senador e ex-governador Moysés Lupion; na UDN, o senador Othon Mader venceu a disputa interna com o Cel. Francisco de Paula Soares Neto e foi oficializado como o candidato do partido; o PSP lançou o deputado federal Luís Carlos Tourinho (filho do Cel. Plínio Tourinho), o candidato a deputado federal mais votado nas eleições de 1954; por fim, o PSB concorreu com Carlos Amoreti Osório.

Com a desunião das forças oposicionistas, a vitória de Lupion era previsível $^{57}$, uma vez que o ex-governador ainda gozava de grande prestígio junto ao eleitorado paranaense, além de também controlar a grande imprensa do estado e investir muitos recursos financeiros em sua campanha.

Além de não possuir a mesma força política e econômica de Lupion, o candidato petebista Mário de Barros também não foi unanimidade dentro do próprio partido, uma vez que diversos petebistas declaravam publicamente a sua oposição à candidatura de Mário de Barros ${ }^{58}$, aversão esta também compartilhada em diversos diretórios do interior do estado. Inclusive, muitos petebistas apoiaram a candidatura de Lupion. Portanto, o PTB encontrava-se desunido

57 Moysés Lupion sagrou-se vencedor no pleito de 3 de outubro, obtendo $40,8 \%$ dos votos, contra 28,9\% de Mário de Barros (PTB), 14,6\% de Othon Mader (UDN), 10,1\% de Luís Carlos Tourinho (PSP) e 0,1\% de Carlos Amoreti Osório (PSB) (IPARDES, 1989, p. 11).

58 Dentre eles Parahylio Borba, Raul de Rezende Filho, Sebastião Vieira Lins, Gastão Vieira de Alencar, Alcides do Amaral Barcellos, Waldemar Daros, entre outros. 
justamente na primeira eleição em que concorreu com candidato próprio ao governo do estado.

\section{Abilon de Souza Naves e a oposição a Moysés Lupion}

No Paraná, a vitória de Moysés Lupion com o apoio de um significativo grupo do PTB poderia ser um indício de que poderia haver uma coalizão entre os petebistas paranaenses e o governador. No entanto, Souza Naves e outras lideranças trabalhistas preferiram inicialmente adotar uma posição de cautela, uma vez que não confiavam em Lupion, sobretudo após o tratamento despendido pelo governador ao PTB durante o seu primeiro governo (1947-1951).

Logo no início do seu segundo mandato, Lupion tentou cooptar o PTB, oferecendo ao partido a Secretaria de Trabalho e Assistência Social e nomeando para esse cargo o deputado federal petebista Cid Campelo. No entanto, a estratégia adotada pelo governador para atrair o PTB para a sua órbita não surtiu o efeito esperado, uma vez que Souza Naves exigia mais do que apenas cargos periféricos.

Diferentemente da época do primeiro governo Lupion, agora o PTB encontrava-se estruturado e consolidado como um partido popular e forte eleitoralmente. Em virtude disso, Souza Naves e outras lideranças trabalhistas argumentavam que o PTB deveria ter uma maior participação no governo estadual e que deveria ser realmente valorizado - demonstrando, assim, que não havia esquecido o tratamento dado ao partido por Lupion no seu primeiro governo.

Embora Lupion tentasse sistematicamente seduzir Souza Naves, as negociações tornaram-se longas e nunca se chegou a um consenso entre ambos os lados. Assim, sem um acordo oficial, Souza Naves optou em fazer oposição a Lupion, contando com o apoio de importantes lideranças dentro do partido, como os deputados estaduais Antônio Annibelli, Jorge de Lima, Pedro Liberti e Joaquim Néia de Oliveira, que eram contrários à aproximação do PTB com o 
governador. Outro grupo que também era contrário à aproximação com Lupion era o dos "pragmáticos reformistas", que estavam ganhando espaço nas hostes petebistas.

Por outro lado, havia uma fração fisiológica dento do partido que defendia a coalizão com o governador, do qual faziam parte os deputados federais Cid Campelo - nomeado secretário do Trabalho e Assistência Social -, Divonsir Borba Cortes e Antônio Baby, além de Parahylio Borba, Rubens de Mello Braga, Sebastião Vieira Lins, Estevam Ribeiro de Souza Neto e diversos prefeitos petebistas do interior do estado, que almejavam receber recursos financeiros do governo estadual para as suas prefeituras.

Portanto, o PTB paranaense encontrava-se, mais uma vez, dividido: oficialmente, encontrava-se em oposição a Lupion, porém, a maior parte da bancada petebista na Assembleia Legislativa não imprimia uma oposição sistemática ao governo, mas sim uma posição colaboracionista em alguns momentos. Tal situação catalisou algumas crises internas dentro do partido durante esse período, pois a ala lupionista pressionava constantemente a Comissão Executiva do PTB, sobretudo o presidente Souza Naves, a aliar-se ao PSD e a Lupion.

Apesar das pressões da ala lupionista do PTB e de ser constantemente atacado pela imprensa pessedista/lupionista, Souza Naves mostrava-se irredutível na sua decisão e tinha força política para mantê-la, uma vez que havia se consolidado como a principal liderança dentro do partido, comandando-o com "mão-de-ferro". Com estreitos vínculos com João Goulart, era vice-presidente nacional do PTB e ambicionava lançar-se como candidato ao Senado, em 1958, e ao governo do Paraná, em 1960 - e contava o apoio da direção nacional do partido para isso.

Contudo, a partir de 1957, a ala lupionista do PTB perdeu força dentro do partido, sobretudo após a Convenção Estadual do partido, realizada em fevereiro de 1957, que culminou com o afastamento dos lupionistas da Comissão Executiva estadual. Somase a isso o fato de Lupion estar envolvido em uma série de escândalos ${ }^{59}$ e enfrentar uma forte campanha oposicionista ao seu

59 Em janeiro de 1957 explodiu o escândalo da Companhia Paranaense de Eletricidade (COPEL), quando o jornal Estado do Paraná denunciou que a empresa, então dirigida por José 
governo em virtude dos conflitos agrários na região sudoeste do estado $^{60}$, que culminou, em outubro de 1957, na Revolta dos Posseiros ou Revolta dos Colonos ${ }^{61}$.

\section{A ascensão dos "pragmáticos reformistas" e da ala "plutocrata” no PTB paranaense}

No dia 24 de fevereiro de 1957 ocorreu a Convenção Estadual do PTB do Paraná, que, inclusive, contou com a presença de João Goulart, vice-presidente da República e presidente nacional do partido, que participou da inauguração da estátua de Getúlio Vargas na Praça Tiradentes.

Durante a Convenção, João Goulart salientou a importância do PTB em seguir a linha doutrinária do trabalhismo, fortemente ancorada em princípios nacionalistas e nos ideais de Getúlio Vargas.

Lupion, irmão do governador, havia comprado um alqueire de terras na cidade de Piraquara por um preço considerado absurdo (na época, 1,5 milhões de cruzeiros). Acrescenta-se a isso o fato da propriedade comprada pela COPEL pertencer ao próprio José Lupion. O escândalo resultou na demissão de José Lupion e no rompimento entre os dois irmãos.

60 José Pedro Kunhavalik (2004, p.197) e Maria Cristina Colnaghi (1991, p. 14-15) dizem que Lupion procurou favorecer na região a Clevelândia Industrial e Territorial Ltda (CITLA) - de quem era "sócio oculto" - em detrimento dos colonos e posseiros. A CITLA, que atuava livremente na região, utilizava-se, por meio de capangas, de métodos arbitrários e violentos para persuadir e intimidar os colonos e posseiros que se recusavam a com eles negociar. Em último caso, chegavam a expulsá-los das terras. A situação na região tendia a torna-se ainda mais crítica à medida que as autoridades eram coniventes com as arbitrariedades e violências - tais como saques, espancamentos (inclusive de mulheres e crianças), incêndios a casas e galpões, destruição de plantações, morte de animais, extorsões, mutilações, estupros e assassinatos - cometidas pelos jagunços das companhias colonizadoras contra os colonos, o que tornou a região "uma terra sem lei".

61 Cansados da inércia do governo em solucionar o problema agrário na região, cerca de seis mil colonos e posseiros, no dia 10 de outubro de 1957, pegaram em armas e se apoderaram dos principais municípios do sudoeste paranaense, como Pato Branco e Francisco Beltrão. Segundo Maria Cristina Colnaghi (1991, p. 18), o grande mérito do movimento agrário no sudoeste paranaense foi a expulsão da CITLA, o que trouxe, na verdade, apenas uma vitória parcial ao movimento, já que muitos continuavam ainda sendo posseiros e vivendo numa situação instável e insegura até meados da década de 1960 - quando a questão agrária efetivamente foi encaminhada para uma solução definitiva. 


\section{Jango também acompanhou de perto a definição dos petebistas paranaenses em manter-se em oposição ao governo Lupion e da escolha da nova Comissão Executiva ${ }^{62}$, presidida por Abilon de Souza Naves.}

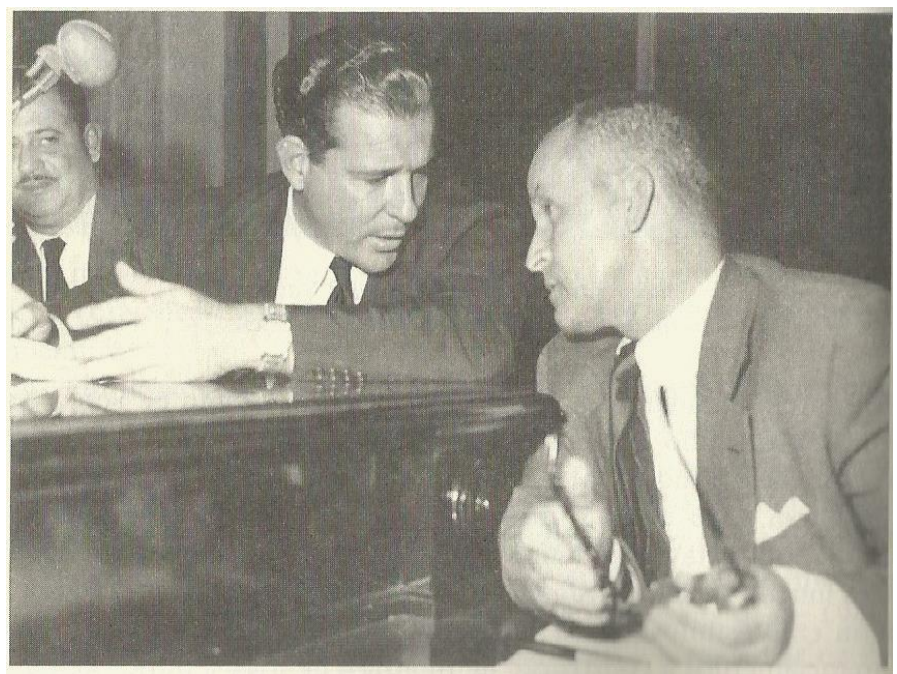

Imagem 2 João Goulart e Souza Naves na Convenção do PTB paranaense (fevereiro/1957). Fonte: acervo pessoal de Léo de Almeida Neves (NEVES, 2002, p. 142).

62 A nova Executiva do PTB do Paraná ficou assim constituída: presidente: Abilon de Souza Naves; primeiro vice-presidente: Antônio Annibelli (deputado estadual e advogado em Clevelândia); segundo vide-presidente: Mário de Barros (deputado estadual e médico em Curitiba); terceiro vice-presidente: Jacinto Cunha (radialista da Rádio Clube Paranaense, de Curitiba); quarto vice-presidente: Gen. Iberê de Mattos (militar com atuação em Curitiba); secretário geral: Léo de Almeida Neves (advogado e jornalista em Curitiba); primeiro secretário: Raul de Rezende Filho (deputado estadual e cafeicultor na região de Jacarezinho); segundo secretário: Pedro Mariucci (deputado estadual e comerciante em Cornélio Procópio); terceiro secretário: José Teixeira da Silva (deputado estadual e médico em Nova Esperança); tesoureiro geral: José Campelli Filho (dentista em Curitiba); primeiro tesoureiro: Libâneo Cardoso (deputado estadual e médico em Castro); segundo tesoureiro: Walter Guimarães da Costa (prefeito de São Jerônimo da Serra); terceiro tesoureiro: João Wagner (líder sindical em Curitiba); conselho fiscal: Antônio Baby (deputado federal e líder ferroviário em União da Vitória), João Cernicchiaro (comerciante em Arapongas) e Herculano Rubim de Toledo (proprietário rural em Paranavaí) (O Estado do Paraná , 26 fev. 1957, p. 16). 
A Convenção também marcou a ascensão do deputado estadual Antônio Annibelli, elencado ao posto de primeiro vicepresidente - o que, na prática, significava o exercício efetivo da presidência, uma vez que Souza Naves estava vivendo no Rio de Janeiro, onde exercia a presidência do Crédito Agrícola e Industrial (CREAI) do Banco do Brasil e integrava a Executiva Nacional do partido. Portanto, a ascensão de Antônio Annibelli, que se destacava pela combatividade a Lupion, era sintomática: as chances de entendimento com o governador estavam liquidadas.

Ademais, convém ressaltar que houve uma significativa renovação na Executiva Estadual, com o afastamento dos lupionistas - como o deputado federal Divonsir Borba Cortes, do ex-secretário geral Alexandre Zainko e dos ex-membros do conselho fiscal Estevam Ribeiro de Souza Neto e Parahylio Borba. Aliás, a Convenção significou a derrota definitiva de Parahylio Borba, que migrou para o PSP.

Dentre os novos integrantes da Executiva do PTB paranaense destacava-se um grupo de trabalhistas defensores de um programa nacionalista e reformista, formado pelos deputados estaduais Mário de Barros (candidato do PTB ao governo do Paraná em 1955) e José Teixeira da Silveira ${ }^{63}$, pelo gen. Iberê de Mattos ${ }^{64}$ e pelo jovem advogado e jornalista Léo de Almeida Neves, membro da Mocidade Trabalhista do Paraná e que, aos 25 anos de idade, foi elencado ao posto de Secretário Geral.

Além de possuir fortes vínculos de amizade com Souza Naves, Léo de Almeida Neves destacava-se por seus artigos e ideias próximas à doutrina pasqualinista, o que lhe rendeu o apelido de "Pasqualini paranaense", tornando-se o principal expoente do grupo dos "pragmáticos reformistas" do PTB do Paraná. Além disso, Léo de Almeida Neves também era um bom orador e Souza Naves, "que era

63 José Teixeira da Silveira era médico e irmão de Roberto Teixeira da Silveira (do PTB-RJ e governador do estado do Rio de Janeiro entre 1959-1961). Em 1958, foi eleito deputado federal, sendo o único parlamentar paranaense a integrar a Frente Parlamentar Nacionalista entre 1958 e 1962.

$64 \mathrm{O}$ gen. Iberê de Mattos era engenheiro civil e ex-diretor da Rede de Viação ParanáSanta Catarina (RVPSC), onde gozava de grande prestígio entre os ferroviários - o que lhe rendeu o apelido de "general do povo". Ingressou no PTB a convite de Souza Naves. Posteriormente, se elegeria prefeito de Curitiba nas eleições de 1958. 
inibido e avesso a discursos públicos, frequentemente o convidava para discursar em seu lugar" (NEVES, 2002, p. 138-139).

Portanto, a Convenção Estadual de fevereiro de 1957 representou o início de uma importante mudança interna no PTB do Paraná com a ascensão de uma ala mais progressista, adepta a um programa nacionalista e reformista, na Executiva estadual - até então amplamente dominada pelos "pragmáticos getulistas".

Por outro lado, Souza Naves, durante o segundo semestre de 1957, intensificou a sua campanha ao Senado e se aproximou dos cafeicultores ${ }^{65}$ do norte do estado, procurando trazê-los para a órbita do PTB, dentre eles Nelson Maculan - então vereador udenista em Londrina e presidente da Associação Rural da mesma cidade. Além dos cafeicultores, Souza Naves também atraiu para o PTB paranaense alguns abastados empresários, como Miguel Buffara, de Paranaguá, Petrônio Fernal, de Ponta Grossa, e Luiz Alberto Dalcanale, da região oeste. Dessa maneira, ascendia no PTB paranaense a "ala dos plutocratas". De acordo com o jornalista e militante comunista Milton Ivan Heller ${ }^{66}$, seus membros "andavam com camisa de seda e possuíam pouca afinidade com o trabalhismo". Sem dúvida, a aproximação de Souza Naves com empresários e cafeicultores tinha o objetivo de garantir ao partido um grande aporte financeiro para a campanha eleitoral de 1958.

Portanto, com a ascensão dos "pragmáticos reformistas" e dos "plutocratas", configurou-se, a partir de 1957, a formação de três principais tendências dentro do PTB paranaense:

- A "ala plutocrata" do PTB: formada por empresários e cafeicultores que ingressaram no partido por intermédio de Souza Naves. Em geral, era um grupo conservador e fisiológico com pouca afinidade com o trabalhismo, cuja base política encontrava-se na região norte do estado.

65 Inclusive, o Cel. Francisco de Paula Soares, presidente da UDN do Paraná, passou a acusar Souza Naves de utilizar a sua condição de presidente da Carteira Agrícola e Industrial (CREAI) do Banco do Brasil - cargo que ocupou de março de 1956 a julho de 1958 - para facilitar crédito agrícola junto aos fazendeiros do norte do estado, com claros objetivos eleitoreiros (Cf. $O$ Dia, 30 out. 1957 , p. 1).

66 Ver o depoimento de Milton Heller em: CODATO; KIELLER, 2008, p. 103. 
- o "PTB do centro": liderado por Souza Naves, era o grupo mais numeroso do partido, reunindo políticos e profissionais liberais da corrente "pragmático getulista".

- e o "PTB progressista" ou "pragmático-reformista": composta pelos adepto dos ideais nacionalistas e reformistas, cujo principal expoente era Léo de Almeida Neves. Essa ala, no final da década de 1950, passou a dominar o Diretório Municipal de Curitiba, que se tornou a principal base política desse grupo.

Por sua vez, Souza Naves liderava e aglutinava, com eficiência, as três correntes que existiam dentro do PTB paranaense, uma vez que era um político paciente, conciliador e muito pragmático.

\section{O ingresso de Jânio Quadros no PTB do Paraná e as eleições de 1958}

Abilon de Souza Naves, durante o ano de 1957, adotou uma série de estratégias cujo objetivo era fortalecer o PTB e a sua candidatura ao Senado: esvaziou a ala lupionista e descartou qualquer possibilidade de entendimento com Lupion; atraiu para o partido alguns empresários e cafeicultores que disponibilizariam um importante aporte financeiro para a campanha eleitoral; convidou os deputados dissidentes do Partido Republicano - Amaury de Oliveira e Silva, Silvino Lopes de Oliveira e Chafic Cury - a ingressarem no PTB; e, por fim, deu uma grande cartada: aproximou-se de Jânio Quadros e propôs que o governador de São Paulo concorresse a deputado federal pelo PTB do Paraná.

Sem dúvida, o convite de Souza Naves a Jânio Quadros tinha um claro objetivo eleitoral: encorpar o PTB paranaense com um político popular e conhecido nacionalmente, que pudesse atrair mais eleitores para o partido - sobretudo da região norte do estado, onde muitos eram de origem paulista. E como Jânio estava impedido de 
disputar algum cargo eletivo em São Paulo, a proposta de concorrer como deputado federal pelo Paraná lhe agradou, pois assim ele teria a possibilidade de ocupar uma cadeira na Câmara dos Deputados até as eleições presidenciais de 1960, a sua grande ambição.

A confirmação da candidatura de Jânio Quadros pelo PTB paranaense ocorreu na Convenção Estadual de 14 de dezembro de 1957, na qual foram lançados 17 candidatos à Câmara dos Deputados e 50 candidatos à Assembleia Legislativa, além de também oficializar-se a candidatura de Souza Naves para o Senado e a de Nelson Maculan como seu suplente (Gazeta do Povo, 17 dez. 1957, p. $3)$.

No entanto, a presença de candidatos milionários, que gastavam fortunas em suas campanhas eleitorais, provocou grandes descontentamentos em alguns grupos dentro do PTB, que, poucos meses antes do pleito de outubro de 1958, utilizando-se de um conhecido clichê janista, denunciavam a disputa do "milhão contra o tostão" nas hostes trabalhistas. Dessa forma, ocorreu uma polarização e fomentou-se uma rivalidade entre os candidatos petebistas: de um lado, estava a "ala dos ricos" ${ }^{67}$ "; de outro, a "ala dos pobres ${ }^{68,}$, que acusavam os "plutocratas" de utilizar o seu poderio econômico para comprar diretórios e contratar cabos eleitorais - que explicitamente compravam votos - em suas regiões de origem, exercendo, assim, uma concorrência desleal. Dessa forma, as disputas pelas bases eleitorais regionais entre os petebistas da "ala rica" e da "ala pobre" contribuíram para acirrar os ânimos dentro do partido,

À medida que as eleições de outubro se aproximavam, os jornais pessedistas também passaram a denunciar, com visíveis intenções eleitorais, a aproximação, no âmbito nacional, entre o PTB

67 A denominada "ala dos ricos" era liderada pelo deputado estadual Miguel Buffara (um dos homens mais ricos do Paraná e que concorria à Câmara dos Deputados), o deputado estadual Libâneo Cardoso (que concorria à reeleição), o deputado federal Heitor Pereira Filho (que também concorria à reeleição), Luiz Alberto Dalcanale (que concorria à deputado estadual) e os candidatos à deputado federal Kalil Maia Neto e Petrônio Fernal.

68 Por sua vez, a "ala dos pobres" era capitaneada pelos deputados estaduais antilupionistas Antônio Annibelli (que concorria à reeleição) e Jorge de Lima (que concorria à Câmara dos Deputados), além do deputado federal Antônio Baby (que concorria à reeleição), do deputado estadual José Teixeira da Silveira (que concorria à Câmara), do deputado estadual Domício Scaramella (que concorria à reeleição) e dos candidatos a deputados estaduais Waldemar Daros e Chafic Cury, entre outros. 
e o $\mathrm{PCB}^{69}$, ao mesmo tempo em que destacavam notícias em que a Igreja católica "condenava tais atividades subversivas". No entanto, a aliança entre comunistas e trabalhistas era constantemente negada por Souza Naves e os demais candidatos petebistas nos comícios e na imprensa.

Não obstante as disputas internas e os contundentes ataques da imprensa pessedista, o PTB do Paraná obteve um excelente desempenho nas eleições de outubro de 1958, elegendo Souza Naves senador, conquistando a prefeitura de Curitiba com o gen. Iberê de Mattos e aumentando o número de deputados em nível federal e estadual.

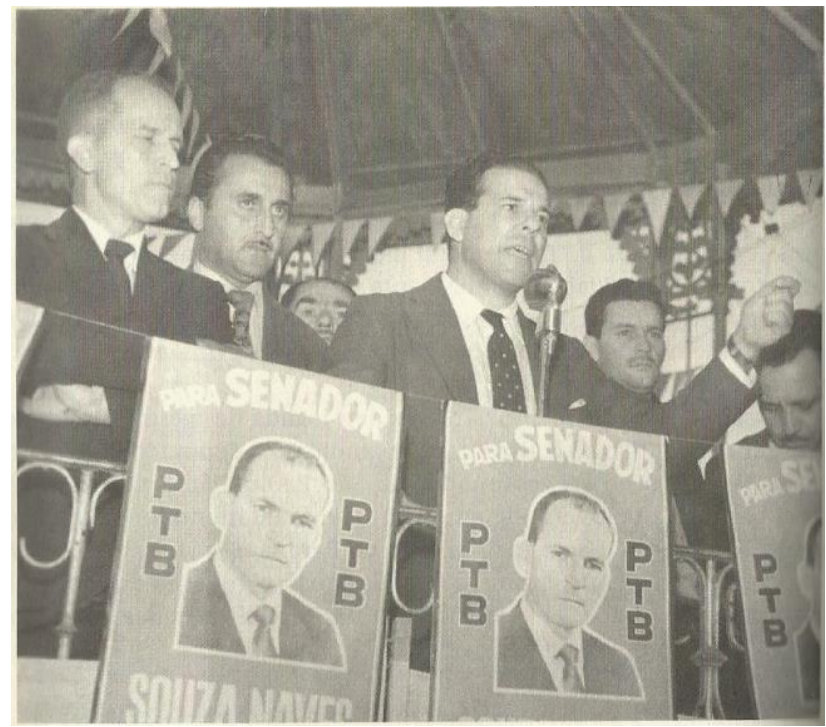

Imagem 3 Campanha de Souza Naves ao Senado em 1958. João Goulart discursando em um comício em Curitiba, em outubro de 1958. À esquerda Souza Naves, candidato ao Senado; no centro, Miguel Buffara, empresário e deputado estadual.

Fonte: Arquivo pessoal de Léo de Almeida Neves (NEVES, 2002, p. 144).

69 Nesse sentido, convém lembrar que o imaginário anticomunista foi uma estratégia eleitoral amplamente utilizada nos anos 1950 e 1960, durante o período da Guerra Fria, visando atingir principalmente o eleitorado conservador. 
Abilon de Souza Naves tornou-se o primeiro senador trabalhista do Paraná - derrotando o candidato lupionista José Munhoz de Melo (PSD) e o udenista cel. Francisco Paula Soares Neto (que concorreu pela Frente Democrática, coligação entre UDN, PR e PSP) -, elegendo-se com uma grande margem de votos. A euforia dos petebistas era tamanha que se dizia, nos círculos políticos paranaenses, que Souza Naves era o governador virtualmente eleito em 1960.

$\mathrm{Na}$ disputa pela prefeitura de Curitiba - um dos postos políticos mais cobiçados entre os partidos - o PTB também conquistou mais uma grande vitória, elegendo o gen. Iberê de Mattos prefeito da capital. Além de derrotar o seu cunhado Luiz Carlos Tourinho (PSP), o Gen. Iberê também derrotou Felipe Simão, que contava com o apoio do atual prefeito Ney Braga, que - embora gozasse de grande prestígio e estava em ascensão política ${ }^{70}-$ não conseguiu eleger o seu sucessor.

Na Câmara dos Deputados, o PTB ${ }^{71}$ também obteve um excelente desempenho, elegendo seis deputados; enquanto o PSD elegeu quatro, a Frente Democrática (UDN-PR-PSP) elegeu dois, o PRP elegeu um (Plínio Salgado, o grande líder do integralismo nacional) e o emergente PDC também um deputado (Ney Braga, na época prefeito de Curitiba).

No que tange às eleições à Assembleia Legislativa, embora o $\mathrm{PTB}^{72}$ também tenha apresentado um crescimento, passando de 11 para 13 deputados, o grande vencedor foi o PSD, que aumentou a sua bancada em seis deputados, passando de 11 para 17 , enquanto a Frente Democrática (formada por UDN e PR) elegeu sete deputados, o PSP quatro, o PDC três; e a Frente Trabalhista Cristã (coligação entre PRP, PTN e PRT) elegeu um deputado.

70 Ney Braga foi o segundo candidato mais votado a deputado federal no Paraná, ficando atrás somente de Jânio Quadros.

71 O PTB elegeu os seguintes deputados federais: Jânio Quadros (o governador de São Paulo foi o deputado federal mais votado no Paraná); Petrônio Fernal, Miguel Buffara, José Teixeira da Silveira, Jorge de Lima e Antônio Baby.

72 O PTB elegeu os seguintes deputados estaduais: Jorge Miguel Nassar, Antônio Annibelli, Luiz Alberto Dalcanale, Joaquim Néia de Oliveira, Miguel Dinizo, Elias Nacle, Mário de Barros, Libâneo Cardoso, José Hoffmann, Silvino Lopes de Oliveira, Pedro Liberti, Amaury de Oliveira e Silva e Waldemar Daros. 
Portanto, as eleições de 1958, do ponto de vista eleitoral, foram um grande divisor de águas para o Partido Trabalhista Brasileiro no Paraná. Adotando uma postura oposicionista ao governo Lupion e à prefeitura de Ney Braga, o partido apresentou, de uma maneira geral, um significativo crescimento eleitoral e consolidou-se como uma grande força política no Paraná.

Por fim, o crescimento eleitoral do PTB paranaense deve-se não necessariamente a adoção de uma plataforma nacionalista e reformista, mas, principalmente, a dois outros fatores. Em primeiro lugar, ao pragmatismo de Souza Naves, que, além de utilizar o legado simbólico getulista-trabalhista, atraiu grande quantidade de recursos financeiros para a campanha eleitoral do partido à medida que se aproximou dos cafeicultores e de setores empresariais. Em segundo lugar, também se deve levar em consideração a inclusão de Jânio Quadros na chapa petebista, que angariou muitos votos para a legenda e contribuiu para a eleição de alguns deputados.

\section{Souza Naves e a defesa da chapa "Jan-Jan"}

Após as eleições de 1958, o PTB paranaense manteve a sua posição oposicionista ao governo Lupion e se articulava para a sucessão estadual de 1960, cujo candidato seria o agora senador Abilon de Souza Naves. Embora os petebistas esbanjassem otimismo e acreditassem que Souza Naves já estava virtualmente eleito governador do Paraná, durante o ano de 1959 também começou a ganhar terreno a candidatura do agora deputado federal e ex-prefeito de Curitiba Ney Braga, do PDC.

Em campanha eleitoral, Souza Naves e Ney Braga iniciaram uma guerra de bastidores, cortejando sistematicamente Jânio Quadros, visando a conquistar o seu apoio no pleito de 1960. Sem dúvida, quem conquistasse o apoio do ex-governador paulista (e agora deputado federal pelo PTB do Paraná) teria um grande trunfo, que certamente garantiria muitos votos. 
Por sua vez, Jânio Quadros, que articulava a sua candidatura à presidência da República pelo $\mathrm{PDC}$, possuía vínculos políticopartidários tanto com o PDC de Ney Braga quanto com o PTB de Souza Naves. Assim, Jânio optou pela neutralidade, embora barganhasse o apoio do PDC e do PTB paranaense à sua candidatura presidencial.

A partir de uma estratégia política regional, uma vez que a eleição de 1958 havia comprovado de que o apoio de Jânio Quadros tinha um peso eleitoral significativo no Paraná, Souza Naves e outros líderes do PTB paranaense passaram a defender a candidatura de Jânio Quadros pelo PTB, passando a articular uma aliança denominada "Jan-Jan" (Jânio e Jango). Embora Souza Naves tentasse convencer João Goulart, a chapa Jan-Jan era combatida por algumas alas - como o grupo de Leonel Brizola e, sobretudo, as correntes nacionalistas. Assim, a candidatura de Jânio pelo PTB acabou sendo gradativamente descartada dentro do partido, ao mesmo tempo em que cresciam as possibilidades de uma nova aliança com o PSD em torno da chapa Lott-Jango.

Em entrevistas a jornais, Souza Naves mostrava-se descontente com a provável aliança com o PSD, declarando que "se isso ocorresse se manteria neutro, pois não poderia aliar-se com o PSD paranaense, a quem fazia oposição" (Gazeta do Povo, 19 maio 1959, p. 3). Na verdade, Souza Naves encontrava-se em uma encruzilhada: além de ser amigo de Jânio Quadros, também ambicionava contar com o seu valioso apoio para as eleições estaduais de 1960, repetindo, assim, a fórmula de sucesso utilizada no pleito de 1958. Porém, também tinha ciência de que a confirmação do acordo com o PSD e o lançamento da chapa Lott-Jango para a sucessão presidencial afastaria qualquer possibilidade de contar com o apoio oficial de Jânio Quadros, que provavelmente tenderia a apoiar a candidatura do seu correligionário pedecista Ney Braga.

Contudo, a insistência de Souza Naves em defender a candidatura Jan-Jan lhe rendeu alguns problemas dentro do PTB nacional, uma vez que passou a sofrer a oposição de algumas alas. Inclusive, a imprensa especulava que João Goulart iria excluí-lo da nova Executiva Nacional, que seria escolhida em outubro de 1959. No entanto, na referida Convenção, Souza Naves foi reeleito pela terceira vez seguida vice-presidente da Executiva Nacional do PTB, 
uma vez que gozava da confiança de João Goulart, de quem era um fiel aliado.

No final de 1959, após a Convenção Nacional trabalhista, Souza Naves passou a adotar uma posição dúbia com relação a Jânio Quadros, negando que houvesse compromissos entre o PTB paranaense e Jânio (Gazeta do Povo, 18 nov. 1959, p. 1), porém não descartando um futuro compromisso, uma vez que ainda possuía esperanças que a chapa Jan-Jan fosse homologada na XII Convenção Nacional do PTB, que seria realizada em fevereiro de 1960.

Entretanto, Souza Naves não viveu para defender a sua posição na Convenção. Em 12 de dezembro de 1959, durante um jantar realizado em sua homenagem (organizado pelos seus excolegas do Instituto de Aposentadorias e Pensões dos Comerciários (IAPC), realizado na Sociedade Morgenau, em Curitiba), sofreu um infarto fulminante e faleceu aos 54 anos de idade.

Durante o funeral de Souza Naves, João Goulart, além de lamentar a morte de seu amigo, mostrava-se preocupado com os rumos do PTB paranaense, que, por sua vez, estava atordoado com a repentina morte do seu líder. Portanto, uma grande incógnita emergia nos círculos políticos paranaenses no final do ano de 1959: como se comportaria o PTB do Paraná sem Souza Naves? Quem comandaria o partido?

Após a morte de Souza Naves, o suplente Nelson Maculan assumiu a sua cadeira no Senado, enquanto o PTB paranaense passou a ser comandado provisoriamente pelo deputado estadual Antônio Annibelli, primeiro vice-presidente. Já na Executiva Nacional, João Goulart indicou Léo de Almeida Neves (então suplente de deputado estadual) para substituir Souza Naves.

Favorecido pelo fato de ter herdado a vaga de Souza Naves no Senado, o "plutocrata" e ex-udenista Nelson Maculan venceu a disputa interna e se tornou o candidato do PTB na sucessão estadual de 1960. Porém, acabou sendo derrotado pelo deputado federal e exprefeito de Curitiba Ney Braga, que emergia como a nova liderança política do Paraná.

Após o pleito de 1960, o PTB do Paraná encontrava-se frustrado pela derrota eleitoral e novamente convulsionado pela disputa dos principais cargos da Executiva Estadual, que seriam definidos na Convenção de janeiro de 1961. Contudo, o grupo 
vencedor, que passou a comandar o PTB a partir da Convenção de 1961, era formado por uma aliança heterogênea entre os membros das três principais tendências petebistas: os "plutocratas", os "pragmáticos getulistas" e os "pragmáticos reformistas". Portanto, após a "era Souza Naves" verificou-se que não houve no PTB do Paraná apenas uma liderança, mas sim três: Nelson Maculan (presidente), Amaury de Oliveira e Silva (primeiro vice-presidente) e Léo de Almeida Neves (secretário geral).

\section{Considerações Finais}

Abilon de Souza Naves esteve à frente do PTB paranaense por mais de dez anos e, desde 1952, integrava a Executiva Nacional do partido. Aliado fiel de João Goulart, Souza Naves, desde 1953, era um dos vices-presidentes nacionais do PTB, chegando a ser, durante um bom período, o presidente em exercício do partido, inclusive desempenhando um papel de destaque nas negociações com o PSD que resultaram na chapa JK-Jango, em 1955. Bom negociador, astuto, ponderado, paciente e aberto ao diálogo, Souza Naves revelou-se um político habilidoso e muito pragmático, cuja prática político-partidária era um amálgama de getulismo, trabalhismo e um nacionalreformismo moderado. Sem dúvidas, Souza Naves desempenhou um importante papel durante o processo de estruturação e consolidação do PTB paranaense ao longo da década de 1950, o que resultou no crescimento eleitoral do partido.

Embora tenha conduzido o PTB paranaense de forma personalista e enfrentou a oposição de alguns grupos, Souza Naves consolidou-se como o principal líder trabalhista do Paraná e a sua liderança conciliou as diferentes frações que existiam dentro do partido, desde as correntes mais conservadoras e fisiológicas até as mais progressistas. 


\section{Referências Bibliográficas}

BODEA, Miguel. Trabalhismo e populismo no Rio Grande do Sul. Porto Alegre: UFRGS, 1992.

CODATO, Adriano; KIELLER, Marcio (Orgs.). Velhos vermelhos: história e memória dos dirigentes comunistas no Paraná. Curitiba: UFPR, 2008.

COLNAGHI, Maria Cristina. O processo político de ocupação do sudoeste. In: PAZ, Francisco Moraes (Org.). Cenários de economia e política: Paraná. Curitiba: Prephacio, 1991, p. 7-23.

COSTA, Samuel Guimarães. História política da Assembléia Legislativa do Paraná. Curitiba: Assembléia Legislativa, 1994, v. 2.

D’ARAUJO, Maria Celina. Sindicatos, carisma \& poder: o PTB de 19451965. Rio de Janeiro: FGV, 1996.

DELGADO, Lucília de Almeida Neves. PTB: do getulismo ao reformismo (1945-1964). São Paulo: Marco Zero, 1989.

DELGADO, Lucilia de Almeida Neves. Trabalhismo, nacionalismo e desenvolvimentismo: um projeto para o Brasil (1945-1964). In: FERREIRA, Jorge (Org.). O populismo e sua história: debate e crítica. Rio de Janeiro: Civilização Brasileira, 2001, p. 167-204.

DELGADO, Lucilia de Almeida Neves. Partidos políticos e frentes parlamentares: projetos, desafios e conflitos na democracia. In: FERREIRA, Jorge; DELGADO, Lucilia de Almeida Neves (Orgs.). O Brasil republicano: o tempo da experiência democrática (1945-1964). Rio de Janeiro: Civilização Brasileira, 2003, v. 3, p. 127-154.

GOMES, Angela Maria de Castro. A invenção do trabalhismo. 3. ed. Rio de Janeiro: FGV, 2005.

GOMES, Angela de Castro. Partido Trabalhista Brasileiro (1945-1965): getulismo, trabalhismo, nacionalismo e reformas de base. In: FERREIRA, Jorge: REIS, Daniel Aarão (Orgs.). Nacionalismo e reformismo radical (1945-1964). Rio de Janeiro: Civilização Brasileira, 2007, v. 2. (Coleção As Esquerdas no Brasil).

GRANOVETTER, Mark S. La fuerza de los vínculos débiles. Política y Sociedad. Madrid, n. 33, 2000, p. 41-56. 
IPARDES. Resultados eleitorais: Paraná (1945-1982). Curitiba: IPARDES, 1989.

KUNHAVALIK, José Pedro. Bento Munhoz da Rocha Netto: trajetória política e gestão no governo do Paraná. In: OLIVEIRA, Ricardo Costa (Org.). A construção do Paraná moderno: políticos e política no governo do Paraná de 1930 a 1980. Curitiba: SETI, 2004, p. 143-230.

MAGALHÃES, Marion Brepohl. Paraná: política e governo. Curitiba: SEED, 2001. (Coleção História do Paraná).

NEVES, Léo de Almeida. Vivência de fatos históricos. São Paulo: Paz e Terra, 2002.

SALLES, Jefferson de Oliveira. A relação entre o poder estatal e as estratégias de formação de um grupo empresarial paranaense nas décadas de 1940-1950: o caso do Grupo Lupion. In: OLIVEIRA, Ricardo Costa (Org.). A construção do Paraná moderno: políticos e política no governo do Paraná de 1930 a 1980. Curitiba: SETI, 2004, p. 35-142.

SAMPAIO, Regina. Adhemar de Barros e o PSP. São Paulo: Global, 1982.

SOARES, Gláucio A. D. Formação dos partidos nacionais. In: FLEISCHER, David V. (Org.). Os partidos políticos no Brasil. Brasília: UnB, 1981, p. 7-24, v. I.

\section{Jornais Pesquisados:}

Diário da Tarde. Curitiba, 1945-1960.

Diário Popular. Curitiba, 1946-1948.

Gazeta do Povo. Curitiba, 1945-1960.

Jornal Trabalhista. Curitiba, 1950.

O Dia. Curitiba, 1945-1960.

O Estado do Paraná. Curitiba, 1951-1960.

RECEBIDO EM: 22/05/2015 APROVADO EM: 18/03/2016 